U.S. Geological Survey National Water Census and Water Availability and Use Science Program

\title{
Application of the Precipitation-Runoff Modeling System (PRMS) To Simulate Near-Native Streamflow in the Upper Rio Grande Basin
}

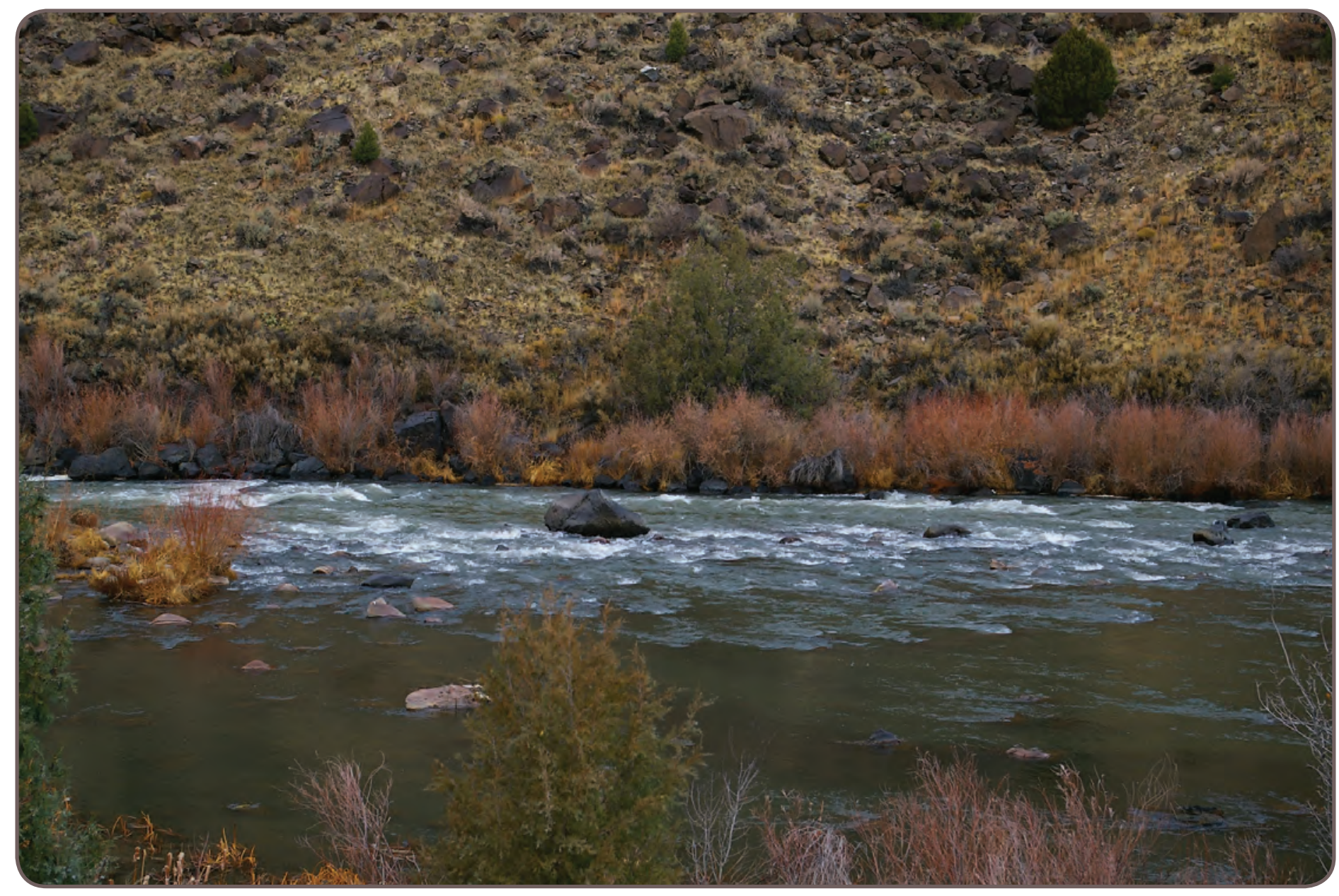

Scientific Investigations Report 2020-5026 
Cover. Rio Grande near Taos Junction Bridge near Taos, New Mexico. Photograph by Jeb Brown, U.S. Geological Survey, October 8, 2014. 


\section{Application of the Precipitation-Runoff Modeling System (PRMS) To Simulate Near-Native Streamflow in the Upper Rio Grande Basin}

By Shaleene B. Chavarria, C. David Moeser, and Kyle R. Douglas-Mankin

U.S. Geological Survey National Water Census and Water Availability and Use Science Program

Scientific Investigations Report 2020-5026 


\title{
U.S. Department of the Interior \\ DAVID BERNHARDT, Secretary
}

\author{
U.S. Geological Survey \\ James F. Reilly II, Director
}

U.S. Geological Survey, Reston, Virginia: 2020

For more information on the USGS - the Federal source for science about the Earth, its natural and living resources, natural hazards, and the environment—visit https://www.usgs.gov or call 1-888-ASK-USGS.

For an overview of USGS information products, including maps, imagery, and publications, visit https://store.usgs.gov/.

Any use of trade, firm, or product names is for descriptive purposes only and does not imply endorsement by the U.S. Government.

Although this information product, for the most part, is in the public domain, it also may contain copyrighted materials as noted in the text. Permission to reproduce copyrighted items must be secured from the copyright owner.

Suggested citation:

Chavarria, S.B., Moeser, C.D., and Douglas-Mankin, K.R., 2020, Application of the Precipitation-Runoff Modeling System (PRMS) to simulate near-native streamflow in the Upper Rio Grande Basin: U.S. Geological Survey Scientific Investigations Report 2020-5026, 38 p., https://doi.org/10.3133/sir20205026.

Associated data for this publication:

Chavarria, S.B., Moeser, C.D., and Shephard, Z., 2020, Input and output data for the application of the PrecipitationRunoff Modeling System (PRMS) to simulate near-native streamflow in the Upper Rio Grande Basin: U.S. Geological Survey data release, https://doi.org/10.5066/P9YOPYW7.

ISSN 2328-0328 (online) 


\section{Contents}

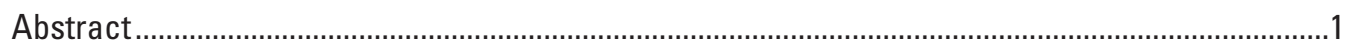

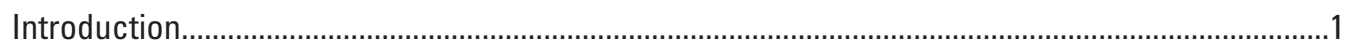

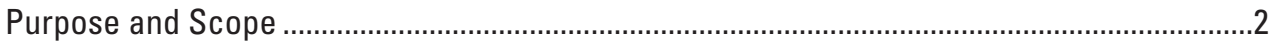

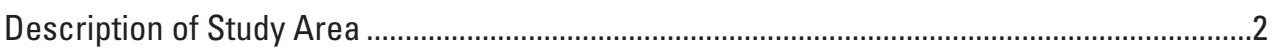

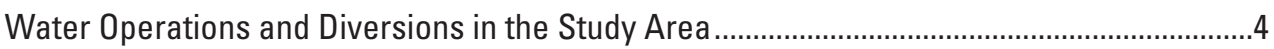

Previous Investigations of Upper Rio Grande Basin Streamflow and Natural Flows ...............4

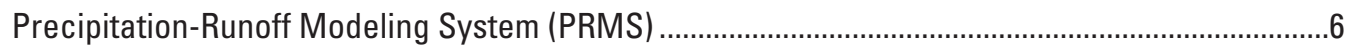

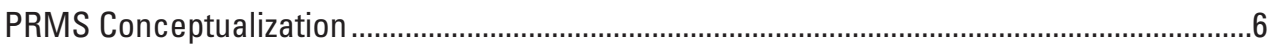

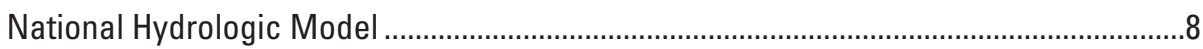

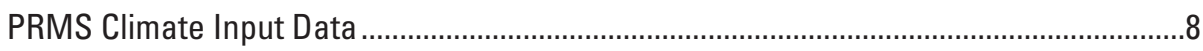

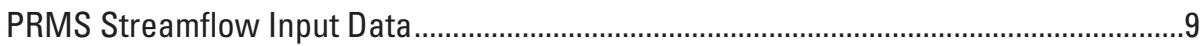

Selection of Near-Native Subbasins ...............................................................................

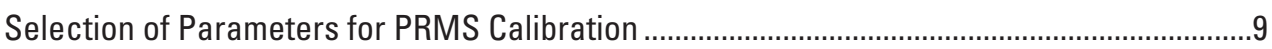

Fourier Amplitude Sensitivity Test (FAST) ..................................................................12

Model Calibration.................................................................................................................

Step 1 \& 2: Solar Radiation, Potential Evapotranspiration.....................................................14

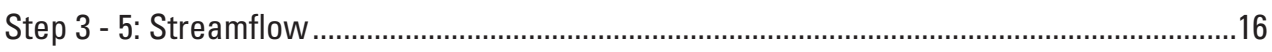

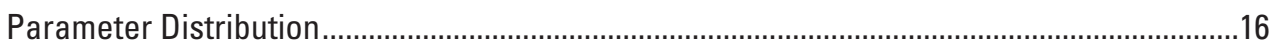

Headwaters Section ................................................................................................

Upper Rio Grande Section.........................................................................................

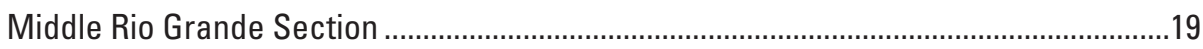

Lower Rio Grande Section ....................................................................................

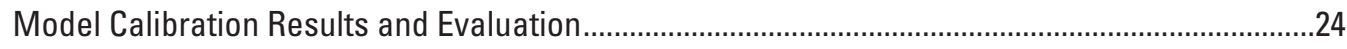

Step 1: Solar Radiation and Potential Evapotranspiration .........................................................24

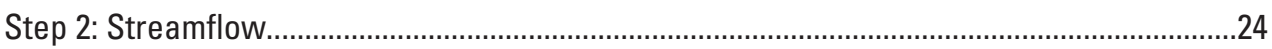

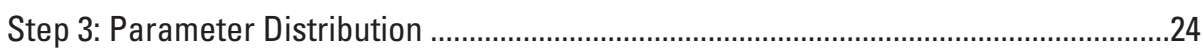

Model Application To Simulate Near-Native Streamflows ...............................................................

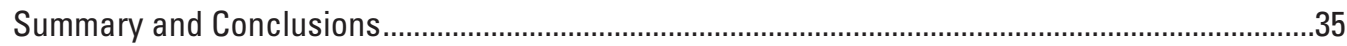

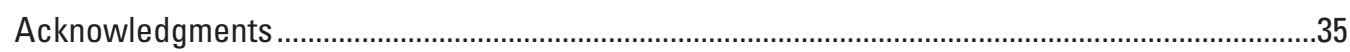

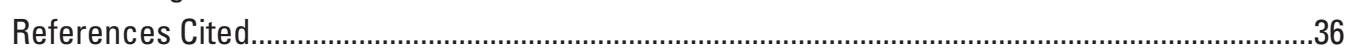

\section{Figures}

1. Map showing location of the Upper Rio Grande Basin study area in Colorado, New Mexico, Texas, and northern Mexico, and its relation to the San Juan River Basin portion of the Colorado River Basin and to the San Luis Valley Closed Basin.

2. Map showing Upper Rio Grande Basin from the headwaters to Fort Quitman, Tex., showing components of the Precipitation-Runoff Modelling System developed for this study, including hydrologic response units, near-native subbasins, parameter distribution sections, and current or former U.S. Geological Survey streamgages 
3. Map showing subareas used in the calibration of solar radiation and potential evapotranspiration, and selected subareas and near-native subbasins

simulated in calibration results.

4. Graph showing parameter interpolation example in an idealized

Precipitation-Runoff Modeling System domain.

5. Graphs showing solar radiation and potential evapotranspiration model simulations for the National Hydrologic Model initial parameters, calibrated parameters, and observed values at the mean monthly time-step for selected subareas in the upper, middle, and lower parts of the Upper Rio Grande Basin and solar radiation and potential evapotranspiration for National Hydrologic Model initial parameters, calibrated parameters, and observed values at the mean monthly time-step for the nine near-native subbasins.

6. Graphs showing hydrographs and cumulative mean daily streamflow model simulations for the National Hydrologic Model initial parameters, calibrated parameters, and observed values for the period 1980-2015

7. Graph showing change in mean daily streamflow from simulated near-native to observed flows in the Upper Rio Grande Basin during the period 1980-2015.

8. Hydrograph of model simulated natural flow and observed mean daily streamflow, and cumulative daily model simulated natural flow and observed streamflow for sites on the mainstem Rio Grande for the period 1980-2015

\section{Tables}

1. Precipitation-Runoff Modeling System calibration parameters.

2. List of all streamgages included in the Upper Rio Grande Basin

Precipitation-Runoff Modeling System model, including streamgages where data were replaced or added for specific streamgaging points in the model.

3. Streamgages selected to represent near-native streamflow conditions in the Upper Rio Grande Basin.

4. Procedure used in the calibration of solar radiation and potential evapotranspiration in 133 subareas, and for calibration of streamflow in the nine near-native subbasins using Luca software.

5. Subbasins used for calibration and validation, periods of record, and summary statistics for nine near-native subbasins of the Upper Rio Grande Basin Precipitation-Runoff Modeling System model

6. Values and parameter dependencies used in parameter distribution scripts for the headwaters section of the Upper Rio Grande Basin

7. Values and parameter dependencies used in parameter distribution scripts for the Upper Rio Grande section of the Upper Rio Grande Basin.

8. Values and parameter dependencies used in parameter distribution scripts for the Middle Rio Grande section of the Upper Rio Grande Basin

9. Values and parameter dependencies used in parameter distribution scripts for the Lower Rio Grande section of the Upper Rio Grande Basin.

10. Mean annual streamflow (1980-2015) and trends for Precipitation-Runoff Modeling System-simulated near-native streamflow and observed streamgage data in the Upper Rio Grande Basin 


\section{Conversion Factors}

U.S. customary units to International System of Units

\begin{tabular}{|c|c|c|}
\hline Multiply & By & To obtain \\
\hline \multicolumn{3}{|c|}{ Length } \\
\hline inch (in.) & 2.54 & centimeter $(\mathrm{cm})$ \\
\hline inch (in.) & 25.4 & millimeter (mm) \\
\hline foot $(\mathrm{ft})$ & 0.3048 & meter (m) \\
\hline mile (mi) & 1.609 & kilometer (km) \\
\hline \multicolumn{3}{|c|}{ Area } \\
\hline acre & 4,047 & square meter $\left(\mathrm{m}^{2}\right)$ \\
\hline acre & 0.4047 & hectare (ha) \\
\hline acre & 0.4047 & square hectometer $\left(\mathrm{hm}^{2}\right)$ \\
\hline acre & 0.004047 & square kilometer $\left(\mathrm{km}^{2}\right)$ \\
\hline square mile (mi²) & 259.0 & hectare (ha) \\
\hline square mile $\left(\mathrm{mi}^{2}\right)$ & 2.590 & square kilometer (km²) \\
\hline \multicolumn{3}{|c|}{ Volume } \\
\hline cubic foot $\left(\mathrm{ft}^{3}\right)$ & 0.02832 & cubic meter $\left(\mathrm{m}^{3}\right)$ \\
\hline acre-foot (acre-ft) & 1,233 & cubic meter $\left(\mathrm{m}^{3}\right)$ \\
\hline \multicolumn{3}{|c|}{ Flow rate } \\
\hline cubic foot per second (ft $3 / \mathrm{s})$ & 0.02832 & cubic meter per second $\left(\mathrm{m}^{3} / \mathrm{s}\right)$ \\
\hline
\end{tabular}

Temperature in degrees Celsius $\left({ }^{\circ} \mathrm{C}\right)$ may be converted to degrees Fahrenheit $\left({ }^{\circ} \mathrm{F}\right)$ as follows: ${ }^{\circ} \mathrm{F}=\left(1.8 \times{ }^{\circ} \mathrm{C}\right)+32$.

Temperature in degrees Fahrenheit $\left({ }^{\circ} \mathrm{F}\right)$ may be converted to degrees Celsius $\left({ }^{\circ} \mathrm{C}\right)$ as follows: ${ }^{\circ} \mathrm{C}=\left({ }^{\circ} \mathrm{F}-32\right) / 1.8$.

\section{Datum}

Vertical coordinate information is referenced to the North American Vertical Datum of 1988 (NAVD 88).

Horizontal coordinate information is referenced to the North American Datum of 1983 (NAD 83).

Elevation, as used in this report, refers to distance above the vertical datum. 


\section{Abbreviations}

$\begin{array}{ll}\text { CODWR } & \text { Colorado Division of Water Resources } \\ \text { HRU } & \text { hydrologic response unit } \\ \text { IBWC } & \text { International Boundary and Water Commission } \\ \text { IDW } & \text { inverse distance weighted } \\ \text { FAST } & \text { Fourier amplitude sensitivity test } \\ \text { Luca } & \text { Let us calibrate } \\ \text { NHM } & \text { National Hydrologic Model } \\ \text { NMOSE/ISC } & \text { New Mexico Office of the State Engineer/Interstate Stream Commission } \\ \text { NRCS } & \text { Natural Resources Conservation Service } \\ \text { NSE } & \text { Nash-Sutcliffe model efficiency } \\ \text { PET } & \text { potential evapotranspiration } \\ \text { PRMS } & \text { Precipitation-Runoff Modeling System } \\ \text { SR } & \text { solar radiation } \\ \text { URGB-PRMS } & \text { Upper Rio Grande Basin PRMS Model } \\ \text { URGWOM } & \text { Upper Rio Grande Water Operations Model } \\ \text { USGS } & \text { U.S. Geological Survey } \\ \text { WOCC } & \text { State of New Mexico Water Quality Control Commission }\end{array}$




\title{
Application of the Precipitation-Runoff Modeling System (PRMS) To Simulate Near-Native Streamflow in the Upper Rio Grande Basin
}

\author{
By Shaleene B. Chavarria, C. David Moeser, and Kyle R. Douglas-Mankin
}

\section{Abstract}

The U.S. Geological Survey's Precipitation-Runoff Modeling System (PRMS) is widely used to simulate the effects of climate, topography, land cover, and soils on landscape-level hydrologic response and streamflow. This study developed, calibrated, and assessed a PRMS model that simulates near-native or naturalized streamflow conditions in the Upper Rio Grande Basin. A PRMS model framework of 1,021 hydrologic response units was constructed for the basin. Subbasins within the larger Upper Rio Grande Basin range from snow-dominated northern basins to monsoon driven southern basins. The 1,021 hydrologic response units were grouped into 133 subareas within the basin, and solar radiation and potential evapotranspiration data were used to calibrate corresponding PRMS parameters in each subarea independently. Nine subbasins with streamgages distributed across the basin were identified as "near-native" subbasins, or those basins with low anthropogenic disturbance. Model parameters that affect streamflow were calibrated for the nearnative subbasins, and the calibrated parameters were distributed to the remaining hydrologic response units on the basis of terrain, soil, and vegetation conditions linked to a distribution and weighting algorithm developed for this study. The parameter distribution method was validated in three of the nine near-native subbasins. Calibration results demonstrated that the PRMS model developed in this study with distributed model parameters for the entire Upper Rio Grande Basin was successful in applying local information to improve model performance over the National Hydrologic Model, and that the new model is appropriate to use to simulate near-native conditions throughout the basin. The result is a model that can simulate naturalized flow and other variables that affect the water budget (including soil moisture, evapotranspiration, recharge) at the daily time step for current and future climate conditions, and that can also be used in conjunction with other models developed for the basin.

\section{Introduction}

Increasing demand for the limited freshwater resources of the United States continues to put pressure on resource management agencies to balance the competing needs of ecosystem health with municipal, agricultural, and other uses (Gonzalez and others, 2018). The U.S. Geological Survey (USGS) National Water Census is a research program focused on water availability and use, called for in the SECURE Water Act and implemented through the Department of the Interior WaterSMART initiative (USGS, 2019a). The overarching purpose of WaterSMART is to develop data and tools needed by resource managers to meet challenges posed by increasingly limited water availability due to aging infrastructure, population growth, groundwater depletion, impaired water quality, water needs for human and environmental uses, and climate variability and change. The objective of the USGS under WaterSMART is to focus on the technical aspects of providing information and tools to stakeholders so that they can make informed decisions on water availability and use.

The Upper Rio Grande serves as the primary source of irrigation water for agriculture throughout the basin, as well as for use by the major municipalities along the river corridor (including the cities of Albuquerque and Las Cruces, New Mexico; El Paso, Texas; and Ciudad Juarez, Chihuahua, Mexico), and environmental and recreational uses in Colorado, New Mexico, and Texas, and in Mexico (fig. 1) (Llewellyn and Vaddey, 2013). Water resources are facing new stresses and demands, and resource managers must understand the role of current and future resource management and development on water availability and sustainability.

In 2016, the Upper Rio Grande Basin in parts of Colorado, New Mexico, Texas, and northern Mexico was chosen as a Focus Area Study for the USGS National Water Census (USGS, 2019a). The conjunctive use of water in the Upper Rio Grande Basin takes place under a myriad of legal constraints including the Rio Grande Compact (Compact) agreement between the States, administration of water rights by individual States, an international treaty with Mexico, and several Federal water projects. The conveyance and use of surface water in the basin is achieved through an engineered 
system of reservoirs, diversions, and irrigation canals designed to deliver water to agricultural, municipal, and industrial users. As populations increase and agricultural crop patterns change, demands for water are increasing, while at the same time the region is experiencing a decrease in supply due to drought and climate change (Gonzalez and others, 2018). The growing gap between supply and demand has resulted in continued conflict over water in the region and ongoing litigation between users and Federal, Tribal, State, and local agencies.

Hydrologic simulation models provide a useful tool to quantify the spatial and temporal distribution of water-budget components in a basin and to assess the effects of climate and land use on water resource availability and timing. The Precipitation-Runoff Modeling System (PRMS) was selected for this study because it is a USGS-developed model based on the National Hydrologic Model (NHM) infrastructure, which provides a consistent model framework (Regan and others, 2019). In addition, PRMS has been calibrated and applied in two other Focus Area Studies, in the Red River and Apalachicola-Chattahoochee-Flint River Basins (USGS, 2019a), and in several other studies in which PRMS is compared to other hydrologic models.

\section{Purpose and Scope}

This report documents the parameterization and calibration of a PRMS model to represent near-native (naturalized) streamflow conditions in the Upper Rio Grande Basin. Near-native or naturalized streamflow, used interchangeably in this report, is defined as streamflow that would occur in the absence of anthropogenic modifications. The model is then used to demonstrate the effect of direct anthropogenic influences on surface water in the basin on the basis of a comparison of streamgage data to simulated near-native streamflow conditions. This model will further allow future studies of change, in terms of land use, climate, and vegetation to be analyzed without having to remove the complex anthropogenic signal of water withdrawal and reservoir storage in the basin.

\section{Description of Study Area}

The Rio Grande, as defined in this study, flows approximately 650 miles from the headwaters in Colorado to Fort Quitman, Texas, draining the 32,000-square mile Upper Rio Grande Basin (fig. 1). The basin spans parts of three States and part of northern Mexico and is an arid to semiarid region where disputes over water shortages have existed for more than 100 years. Basin topography varies from the forested mountains and river gorges of the headwaters to the riparian forests (bosque) of the broad valleys and high desert of central New Mexico, to deserts along the boundary between Texas and Mexico (Llewellyn and Vaddey, 2013).

Climate in the basin varies with elevation and latitude, and this influences streamflow generation. Subbasins in the northern part of the larger Upper Rio Grande Basin produce most of the streamflow volume in the spring and early summer as the snow melts. Most of the streamflow volume in the southern part of the Upper Rio Grande Basin is produced in the spring and early summer seasons, driven by the summer monsoon.

In the headwaters region of the basin, north of the Colorado-New Mexico State line, elevations range from 7,500 feet in the San Luis Valley to more than 14,000 feet in the San Juan and Sangre de Cristo Mountains that border the valley (DiNatale Water Consultants, 2014). Mean annual temperatures in the region range from 24 to 53 degrees Fahrenheit $\left({ }^{\circ} \mathrm{F}\right)$, and mean annual precipitation ranges from 17 to 40 inches, with most of the precipitation falling as snow at high elevations (Llewellyn and Vaddey, 2013; Vose and others, 2014). Seasonal snowpack that builds throughout the winter in the San Juan and Sangre de Cristo Mountains contributes to about 60 to 75 percent of Rio Grande flow (Rango, 2006; Llewellyn and Vaddey, 2013).

The State of New Mexico Water Quality Control Commission (WQCC) defines three regions of the Upper Rio Grande Basin in New Mexico as the Upper, Middle, and Lower Rio Grande (fig. 2). The Upper Rio Grande region extends from the Colorado-New Mexico State line south to about the town of Bernalillo. The Upper Rio Grande region as defined by the WQCC differs from the Upper Rio Grande Basin described in this report in that the Upper Rio Grande region is a small portion of the overall study area.

Elevations in the Upper Rio Grande region range from 5,000 feet to more than 12,000 feet in the Jemez Mountains west of the Rio Grande and in the Sangre de Cristo Mountains east of the river (WQCC, 2002). Mean annual temperatures in the region range from 45 to $55^{\circ} \mathrm{F}$, with lower temperatures occurring at mid to high elevations (New Mexico Office of the State Engineer/Interstate Stream Commission [NMOSE/ISC], 2016a-c). Precipitation in the region is highly variable, falling as snow in the winter and as rain in the summer, when it is driven by the monsoonal weather pattern. Mean annual precipitation ranges from more than 40 inches in the mountainous regions to about 10 inches in the valley along the Rio Grande (NMOSE/ISC, 2016a-c). Most of the perennial tributaries to the Rio Grande in the New Mexico portion of the basin are contained within the Upper Rio Grande region, and major tributaries contribute about 25 percent of Rio Grande flow (WQCC, 2002; Llewellyn and Vaddey, 2013). Collectively, about 80 to 85 percent of Rio Grande flow is generated in the headwater and Upper Rio Grande regions of the Upper Rio Grande Basin.

The Middle Rio Grande region, which extends from Bernalillo to Elephant Butte Reservoir, south of Socorro, consists of mountainous areas and broad plains (WQCC, 2002). Elevations range from more than 10,000 feet in the Sandia Mountains to around 4,000 feet around Socorro. Mean annual temperature in the Middle Rio Grande region ranges from about 50 to $55^{\circ} \mathrm{F}$, and mean annual precipitation ranges from 8 inches in the valley to about 30 inches at higher elevations (NMOSE/ISC, 2017a). Rio Grande flow in the region is sustained primarily by flow generated upstream and from the Arroyo Chico and Rio Puerco Basins (WQCC, 2002). 


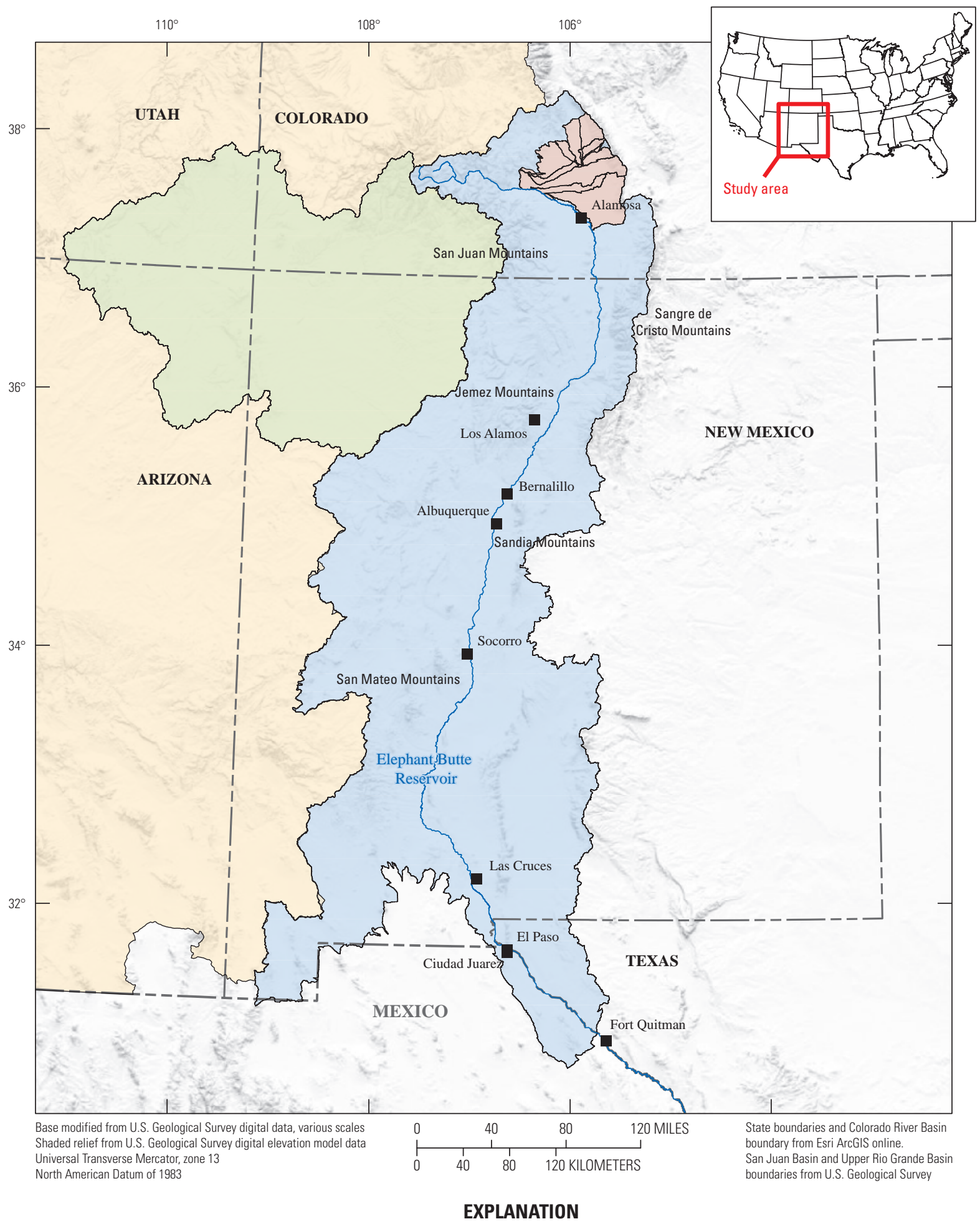

EXPLANATION

San Juan River Basin

Colorado River Basin

San Luis Valley Closed Basin

Upper Rio Grande River Basin

Figure 1. Location of the Upper Rio Grande Basin study area in Colorado, New Mexico, Texas, and northern Mexico, and its relation to the San Juan River Basin portion of the Colorado River Basin and to the San Luis Valley Closed Basin. 
The Lower Rio Grande region, which comprises areas of the Upper Rio Grande Basin south of Elephant Butte Reservoir, is an arid region in which flow in the Rio Grande is influenced primarily by the summer monsoon. Elevations in the region range from about 10,000 feet in the San Mateo Mountains to about 3,800 feet in the southern part of the basin (WQCC, 2002). Mean annual precipitation ranges from about 8 to 18 inches, with most precipitation falling at the higher elevations (NMOSE/ISC, 2017b). Mean annual temperatures range from 50 to $75^{\circ} \mathrm{F}$, and summer temperatures can exceed $100^{\circ} \mathrm{F}$ at lower elevations (NMOSE/ISC, 2017b). Flow in Rio Grande tributaries in the Lower Rio Grande region is predominantly ephemeral (WQCC, 2002).

\section{Water Operations and Diversions in the Study Area}

Rio Grande water is routed through a series of dams along the length of the river and is diverted primarily for agricultural use along the way. Allocation of Rio Grande surface water among States within the Upper Rio Grande Basin is governed by the Rio Grande Compact. The Compact apportions water to Colorado, New Mexico, and Texas, and an international treaty annually allocates up to 60,000 acre-feet of Rio Grande water to Mexico (Paddock, 2001).

Surface-water sources for the Upper Rio Grande Basin include within-basin water as well as water imported from the Colorado River Basin through the San Juan-Chama Project. Approximately 12,000 acre-feet of water per year is diverted from the San Luis Valley Closed Basin in Colorado to the Rio Grande above the Colorado-New Mexico State line, where it is used to help offset groundwater use and to meet Compact obligations (DiNatale Water Consultants, 2014). San Juan-Chama Project water is diverted from the San Juan River Basin portion of the Colorado River Basin (fig. 1) and conveyed by tunnel into the Upper Rio Grande Basin (Glaser, 1998). San Juan-Chama Project water is allocated to many of the major cities and irrigation districts in the basin above Elephant Butte Reservoir. San Juan-Chama pipeline construction was completed in 2008 and until recently, many of the cities and irrigation districts have not been able to use their San Juan-Chama Project allotments. Water operations and management in the Upper Rio Grande Basin is complex because of the different sources of water (within-basin and imported), numerous reservoirs, stream-aquifer relations, and legal constraints. Due to these complexities, Federal and local agencies have developed and are using a tool called the Upper Rio Grande Water Operations Model (URGWOM) (U.S. Army Corps of Engineers and others, 2005) to simulate the complex water operations in daily time steps for real-time operations, and in monthly time steps for planning.

URGWOM is a basin-wide water-operations model that accounts for deliveries, use, and routing of the different sources of water, and forecasts the effects of hypothetical water-operation scenarios in the basin. URGWOM is the main tool for water management and daily operations in the basin above Elephant Butte Reservoir. Model inflows come from 52 tributary inflow points, most of which are defined by observed USGS streamgage data. A current (2019) limitation of URGWOM is that it lacks a process-based representation of hydrologic inflows, which limits its flexibility in forecasting or projecting water operations into near- or distant-future operations. A hydrologic model is needed that can provide daily streamflow timeseries for URGWOM tributary inflows across the Upper Rio Grande Basin, and that allows simulation of climate and land-use change scenarios.

\section{Previous Investigations of Upper Rio Grande Basin Streamflow and Natural Flows}

Several methods have been used to estimate near-native, or naturalized, streamflow in river basins throughout the United States. The estimated values of the naturalized flows are then used for many purposes, including assessing the effect of human modifications on rivers, riparian ecosystems, and aquatic species (Carlisle and others, 2010; Miller and others, 2018a, 2018b; Blythe and Schmidt, 2018); assessing the potential effects of future climate conditions on water resources in a river basin and determining the sensitivity of regulated versus natural flows to climate change (Ficklin and others, 2018; Zhou and others, 2018); and for water management and agricultural purposes (Natural Resources Conservation Service [NRCS], 2019).

A database of natural monthly streamflow estimates was created for the conterminous United States for the period 1950-2015 by using a statistical machine-learning technique known as random forest modeling (Miller and others, 2018a). The technique uses streamflow data from reference sites identified to be relatively unaffected by humans, climate data, and basin characteristic variables that affect streamflow (soil, topography, and precipitation, among others) to create and calibrate random forest models for 10 different modeling regions. The models created for each region are then used to predict monthly natural streamflow for stream segments within a specific region. The naturalized monthly streamflow estimates (Miller and others, 2018b) can then be used to assess human effects on rivers and riparian areas.

The U.S. Department of Agriculture NRCS creates and distributes water supply forecasts, or predictions of streamflow volume, for many sites across the western United States (NRCS, 2019). Water supply forecasts aid in water management and agricultural planning decisions, particularly in the late winter and spring seasons. Monthly streamflow at some sites that are affected by water management upstream from the forecast site is adjusted to represent the volume of water that would be flowing through the site in the absence of upstream reservoirs and diversions (NRCS, 2019).

A method of estimating naturalized flow by using a mass balance model and change point analysis was developed and tested in the northern branch of the Rio Grande (Blythe and Schmidt, 2018). The method calculates natural flow for 33 streamgaging points along the mainstem Rio Grande on 


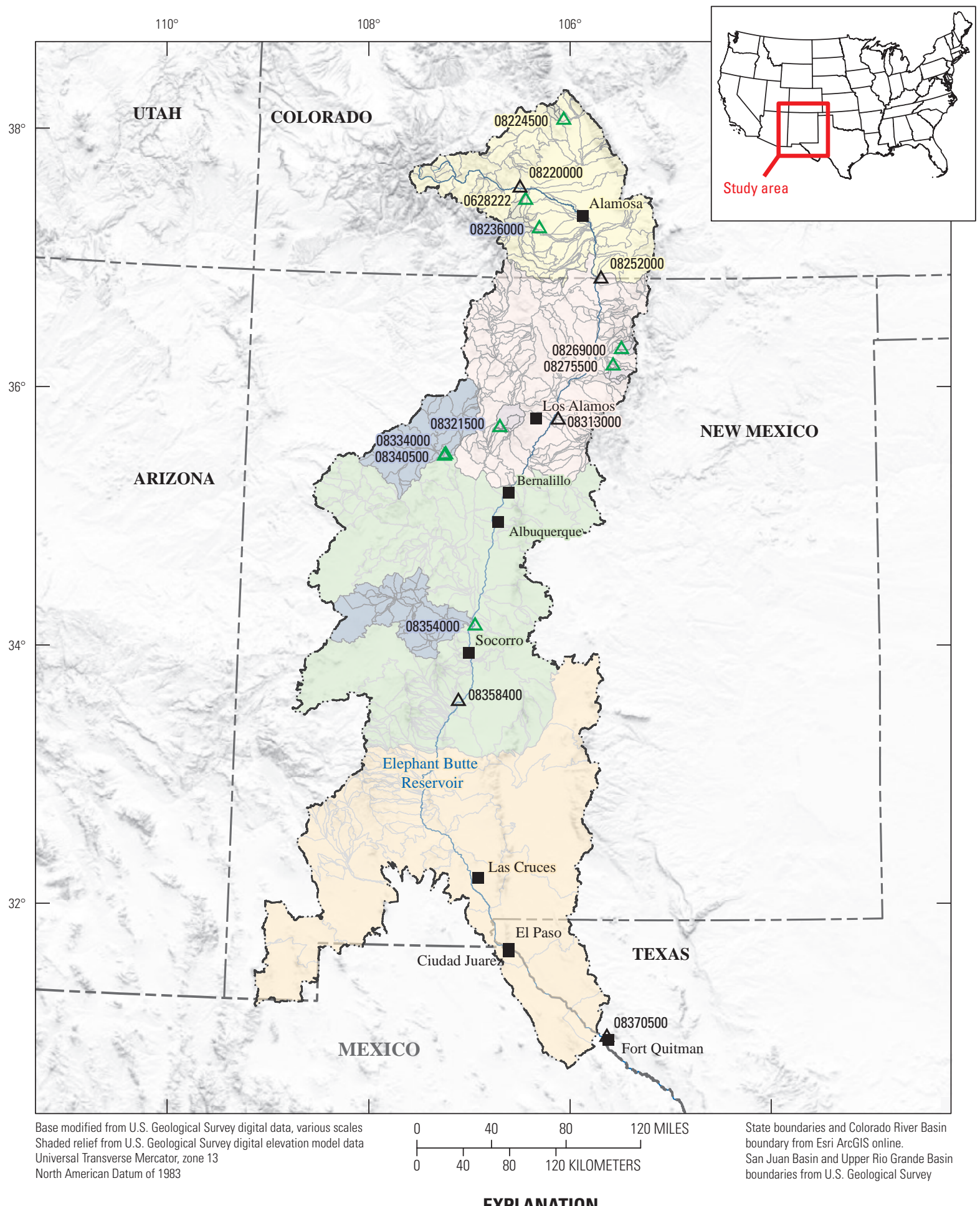

EXPLANATION

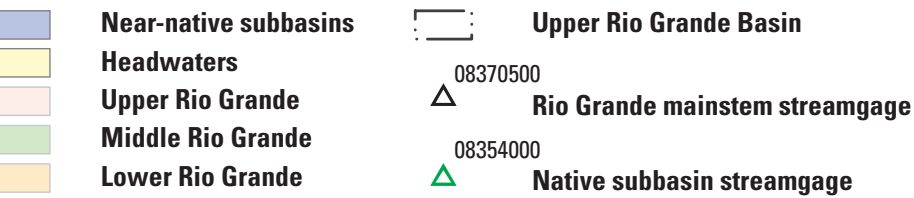

Figure 2. Upper Rio Grande Basin from the headwaters to Fort Quitman, Tex., showing components of the Precipitation-Runoff Modelling System developed for this study, including hydrologic response units (light gray polygons), near-native subbasins, parameter distribution sections [Headwaters; Upper Rio Grande; Middle Rio Grande; Lower Rio Grande], and current or former U.S. Geological Survey streamgages. 
the basis of daily streamflow data, reservoir storage data, and water imported via the San Juan-Chama Project. Blythe and Schmidt (2018) reported that by the end of the twentieth century, total annual flow in the reach between the headwaters of the Rio Grande and Presidio, Tex., had decreased by about 95 percent as a result of anthropogenic influence, and peak flows driven by seasonal snow melt are no longer dominant events in annual hydrographs.

The methods outlined above provide estimates of naturalized streamflow but do not indicate how changes in waterbudget components, such as soil moisture, affect streamflow, or how changes in streamflow affect water-budget components. This report expands upon the above analyses. A basin model valid for the entire Upper Rio Grande Basin that is capable of simulating water budget components was developed on the basis of a much stricter definition of naturalized flows. The model can also be used with future forcing data to assess the potential effect of future climate on water resources in the basin. This allows for the analysis of hydrologic changes in the basin due to changes in land use, climate, and other factors without having to remove the complex nonlinear withdrawals governed by agreements and water laws.

\section{Precipitation-Runoff Modeling System (PRMS)}

The Precipitation-Runoff Modeling System (PRMS) is a component of the National Hydrologic Model (NHM) developed by the USGS (Leavesley and others, 1983; Markstrom and others, 2015). PRMS is a deterministic, process-based, distributed-parameter modeling system designed to analyze the effects of precipitation, climate, and land use on streamflow and general basin hydrology on a daily time step. The national-scale framework of the NHM allows for subcatchment modeling using predefined, spatially distributed hydrologic response units (HRUs) (as described by Regan and others, 2018). HRUs partition the model domain into areas with relatively uniform hydrologic response that are based on basin topography, vegetation, soil, and climate. The model input data include precipitation, minimum temperature, and maximum temperature.

PRMS represents the hydrologic cycle as 17 interconnected processes (Markstrom and others, 2015). These hydrologic processes are simulated using source code modules within PRMS. In some cases, PRMS has several modules that provide alternative methods of simulating the processes. Hydrologic processes simulated in PRMS are temperature distribution, precipitation distribution, combined climate distribution, solar radiation distribution, transpiration period, potential evapotranspiration (PET), canopy interception, snow, surface runoff, soil-zone, groundwater, and streamflow processes, plus five model administrative processes (basin definition, cascading flow, solar table, time-series data, and summary).
Each module in PRMS uses parameters and variables to simulate hydrologic processes. Parameters are user-specified input values that are constant through time (year to year) and can vary spatially across the landscape (unique values per HRU) or vary by month and HRU (giving [HRUs x months] unique values), but do not change during the simulation (for example, the area of each HRU is a parameter that does not change during model simulation). Variables are hydrologic states and fluxes that may change with each time step during the simulation (Markstrom and others, 2015). Some variables may be user-input time-series variables (for example, daily precipitation) or internal variables (for example, soil moisture for each HRU), which are calculated by the modules and may be used by other modules as input variables.

PRMS, like many distributed hydrologic models, needs to be calibrated to be applicable to a specific study area. Although PRMS uses a total of 108 input parameters, 72 of these parameters are not typically varied from their initial values, leaving 36 as standard calibration parameters (table 1). Each calibration parameter is used within a single hydrologicprocess module, but because output variables from one module can be used as input variables to other modules, calibration parameters may influence several modules. PRMS has more than 200 output variables that represent specific hydrologic responses over time. As a result of both model complexity and the extensive set of parameters, sensitivity analyses for PRMS are both highly complex and essential for successful model application. During model sensitivity analysis, the influence of calibration parameters on output variables is assessed. During model calibration, calibration parameters are adjusted, and output variables are compared to observed hydrologic data to assess model performance.

\section{PRMS Conceptualization}

The steps taken to arrive at a PRMS model that simulates near-native streamflow conditions for the Upper Rio Grande Basin, as presented in this report, are to:

1. Develop a model of the Upper Rio Grande Basin based on the USGS NHM infrastructure;

2. Define subbasins within the Upper Rio Grande Basin that have little to no water withdrawals (near-native subbasins);

3. Calibrate model within these near-native subbasins;

4. Distribute calibrated parameter values to the remaining model domain from a newly developed technique that uses local terrain, soil, and vegetation conditions and links this information to a distribution and weighting algorithm (described in the Parameter Distribution section); and

5. Validate calibration and distribution function.

Data associated with each step of model calibration in this report can be found in Chavarria and others (2020). 
Table 1. Precipitation-Runoff Modeling System (PRMS) calibration parameters (modified from Markstrom and others, 2015; Markstrom and others, 2016).

[HRU, hydrologic response unit; ET, evapotranspiration; F, Fahrenheit; in., inch; C, Celsius]

\begin{tabular}{|c|c|c|c|}
\hline Parameter name & Description (units) & PRMS module & Range \\
\hline adjmix_rain & $\begin{array}{l}\text { Factor to adjust rain proportion in a mixed rain/snow event (decimal } \\
\text { fraction) }\end{array}$ & Climate & $0.6-1.4$ \\
\hline tmax_allrain_offset ${ }^{1}$ & $\begin{array}{l}\text { Maximum air temperature above which precipitation is rain (degrees } \\
\text { F) }\end{array}$ & Climate & $0.0-50.0$ \\
\hline tmax_allsnow & $\begin{array}{l}\text { Maximum air temperature below which precipitation is snow (de- } \\
\text { grees F) }\end{array}$ & Climate & $-10.0-40.0$ \\
\hline rain_cbh_adj & $\begin{array}{l}\text { Monthly (January to December) adjustment factor to measured } \\
\text { precipitation determined to be rain on each HRU to account for } \\
\text { differences in elevation, and so forth }\end{array}$ & Climate & $0.5-2.0$ \\
\hline snow_cbh_adj & $\begin{array}{l}\text { Monthly (January to December) adjustment factor to measured } \\
\text { precipitation determined to be snow on each HRU to account for } \\
\text { differences in elevation, and so forth }\end{array}$ & Climate & $0.5-2.0$ \\
\hline dday_intcp & Intercept in degree-day equation (degree-days) & Solar radiation & $-60.0-10.0$ \\
\hline dday_slope & Slope in degree-day equation (degree-days per F) & Solar radiation & $0.2-0.9$ \\
\hline ppt_rad_adj & Solar radiation adjustment threshold for precipitation days (in.) & Solar radiation & $0.0-0.5$ \\
\hline radj_sppt & $\begin{array}{l}\text { Solar radiation adjustment on summer precipitation days (decimal } \\
\text { fraction) }\end{array}$ & Solar radiation & $0.0-1.0$ \\
\hline radj_wppt & $\begin{array}{l}\text { Solar radiation adjustment on winter precipitation days (decimal } \\
\text { fraction) }\end{array}$ & Solar radiation & $0.0-1.0$ \\
\hline radmax & $\begin{array}{l}\text { Maximum solar radiation due to atmospheric effects (decimal frac- } \\
\text { tion) }\end{array}$ & Solar radiation & $0.1-1.0$ \\
\hline tmax_index & $\begin{array}{l}\text { Temperature to determine precipitation adjustments to solar radia- } \\
\text { tion (degrees F) }\end{array}$ & Solar radiation & $-10.0-110.0$ \\
\hline jh_coef & $\begin{array}{l}\text { Coefficient used in Jensen-Haise potential ET computations (per } \\
\text { degrees F) }\end{array}$ & Potential ET & $0.005-0.06$ \\
\hline jh_coef_hru & $\begin{array}{l}\text { Coefficient used in Jensen-Haise potential ET computations (per } \\
\text { degrees F) }\end{array}$ & Potential ET & $5.0-25.0$ \\
\hline srain_intcp & Summer rain interception storage capacity (in.) & Interception & $0.0-1.0$ \\
\hline wrain_intcp & Winter rain interception storage capacity (in.) & Interception & $0.0-1.0$ \\
\hline cecn_coef & $\begin{array}{l}\text { Convection condensation energy coefficient (calories per degree } \mathrm{C} \\
>0 \text { ) }\end{array}$ & Snow & $2.0-10.0$ \\
\hline emis_noppt & $\begin{array}{l}\text { Average emissivity of air on days without precipitation (decimal } \\
\text { fraction) }\end{array}$ & Snow & $0.757-1.0$ \\
\hline freeh2o_cap & Free-water holding capacity of snowpack (decimal fraction) & Snow & $0.01-0.2$ \\
\hline potet_sublim & Snow sublimation fraction of potential ET (decimal fraction) & Snow & $0.1-0.75$ \\
\hline carea_max & Maximum area contributing to surface runoff (decimal fraction) & Surface runoff & $0.0-1.0$ \\
\hline smidx_coef & Nonlinear contributing area coefficient (decimal fraction) & Surface runoff & $0.001-0.06$ \\
\hline smidx_exp & Exponent in nonlinear contributing area coefficient (per in.) & Surface runoff & $0.1-0.5$ \\
\hline fastcoef_lin & $\begin{array}{l}\text { Linear coefficient in equation to route preferential-flow (fraction per } \\
\text { day) }\end{array}$ & Soil-zone & $0.001-0.8$ \\
\hline fastcoef_sq & Nonlinear coefficient in equation to route preferential-flow (none) & Soil-zone & $0.001-1.0$ \\
\hline pref_flow_den & $\begin{array}{l}\text { Fraction of the soil zone in which preferential flow occurs (decimal } \\
\text { fraction) }\end{array}$ & Soil-zone & $0.0-0.1$ \\
\hline sat_threshold & Water capacity between field capacity and total saturation (in.) & Soil-zone & $1.0-999.0$ \\
\hline slowcoef_lin & Linear coefficient for interflow routing (fraction per day) & Soil-zone & $0.001-0.5$ \\
\hline slowcoef_sq & Nonlinear coefficient for interflow routing (none) & Soil-zone & $0.001-1.0$ \\
\hline
\end{tabular}


Table 1. Precipitation-Runoff Modeling System (PRMS) calibration parameters (modified from Markstrom and others, 2015; Markstrom and others, 2016).-Continued

[HRU, hydrologic response unit; ET, evapotranspiration; F, Fahrenheit; in., inch; C, Celsius]

\begin{tabular}{|c|c|c|c|}
\hline Parameter name & Description (units) & PRMS module & Range \\
\hline soil2gw_max & $\begin{array}{l}\text { Maximum soil water excess that is routed directly to groundwater } \\
\text { (in.) }\end{array}$ & Soil-zone & $0.0-0.5$ \\
\hline soil_moist_max & $\begin{array}{l}\text { Maximum available water holding capacity of capillary reservoir, } \\
\text { from land surface to root depth (in.) }\end{array}$ & Soil-zone & $0.001-10.0$ \\
\hline soil_rechr_max_frac ${ }^{1}$ & $\begin{array}{l}\text { Fraction of the capillary reservoir water-holding capacity (soil__ } \\
\text { moist_max) where losses occur as both evaporation and transpira- } \\
\text { tion (upper zone of capillary reservoir) for each HRU }\end{array}$ & Soil-zone & $0.00001-1.0$ \\
\hline ssr2gw_exp & $\begin{array}{l}\text { Nonlinear coefficient in equation used to route soil-zone water to } \\
\text { groundwater (none) }\end{array}$ & Soil-zone & $0.0-3.0$ \\
\hline ssr2gw_rate & $\begin{array}{l}\text { Linear coefficient in equation used to route soil-zone water to } \\
\text { groundwater (fraction per day) }\end{array}$ & Soil-zone & $0.05-0.8$ \\
\hline transp_tmax & $\begin{array}{l}\text { Temperature that determines start of the transpiration period (de- } \\
\text { grees F) }\end{array}$ & Soil-zone & $0.0-1000.0$ \\
\hline gwflow_coef & Linear groundwater discharge coefficient (fraction per day) & Groundwater & $0.001-0.5$ \\
\hline
\end{tabular}

1Parameters changed from PRMS-IV to PRMS-V. PRMS-IV and PRMS-V are sequential versions of PRMS.

\section{National Hydrologic Model}

For this study a PRMS model based on the NHM infrastructure was built for the Upper Rio Grande Basin, extending from the headwaters to the streamgage at Fort Quitman, Tex. (hereafter called the URGB-PRMS model; fig. 2). The NHM infrastructure is a repository where all information, including predefined HRUs, estimated parameters derived from a variety of methods, climate input data, and hydrologic process simulation code, can be obtained to develop and run a PRMS model for a specified area (Regan and others, 2018, 2019). The 1,021 HRUs that cover the study area basin were extracted from the NHM along with model parameters and input data.

Initial input parameter values from the NHM database for Upper Rio Grande Basin HRUs were adopted from the Geospatial Fabric of the NHM platform (Viger, 2014; Viger and Bock, 2014; Regan and others, 2018, 2019). Soil parameters were derived from the Soil Survey Geographic database (NRCS, 2013). Land-cover parameters were derived from the 2001 National Land Cover Database (Homer and others, 2007). Subsurface-flow parameters were derived from the map products of Gleeson and others (2011). Determination of values for other model spatial parameters and initial conditions (such as water content of various model storage pools) are described in Regan and others $(2018,2019)$. The calibrated version of selected parameters (Hay, 2019), maintained by NHM Parameter Database (Driscoll and others, 2017), were used as initial parameters for the URGB-PRMS model.

Prior to model calibration, parameters in the San Luis Valley Closed Basin (hereafter called the Closed Basin; fig. 1) were altered to prohibit water that does not naturally drain to the Rio Grande either by surface drainage or groundwater discharge from moving out of the Closed Basin (DiNatale Water Consultants, 2014). Three parameters (hru_type, ssr2gw_rate, and sat_threshold) in 18 HRUs, covering approximately 1,967 square miles $\left(\mathrm{mi}^{2}\right)$ in the Closed Basin, were changed from default values. Parameters hru_type were changed from 1 (land type hru) to 3 (swale type hru) for each HRU in the Closed Basin. Swales are land-type HRUs that do not simulate surface runoff or lateral flow but capture flow and contribute water only to groundwater flow (Markstrom and others, 2015). The ssr2gw_rate parameters, which route water from the gravity reservoir to the groundwater reservoir for each HRU, were changed from default values to zero for each swale HRU to prevent water from leaving the Closed Basin area through the groundwater reservoir. Lastly, the parameter sat_threshold for each swale type HRU was changed to 2 times the soil_moist_max parameter value, which results in some ponding of water and allows for evapotranspiration from each swale type HRU.

\section{PRMS Climate Input Data}

Daily precipitation, minimum daily temperature, and maximum daily temperature input data for the study period (1980-2015) were obtained from Daymet: Daily Surface Weather Data on a 0.62-mile (mi) (1-kilometer [km]) Grid for North America, Version 3 (Thornton and others, 2016). Daymet is a collection of gridded estimates of precipitation, temperature, and solar radiation derived by interpolation and extrapolation from observation data at climate stations across North America (Thornton and others, 2016) and a digital elevation model. 


\section{PRMS Streamflow Input Data}

A file containing a list of USGS streamgages and observed streamflow data at the listed streamgages is required for PRMS. The observational data are not used for model simulation, but rather can be used for calibration purposes or can be specified as an output variable along with simulated variables for plotting or analysis. A total of 92 streamgages with varying periods of record were included in the URGB-PRMS data file (table 2). USGS streamflow data were used primarily where the streamgages existed and had adequate periods of record (USGS, 2019b). For multiple points in the URGBPRMS model, specifically in Colorado and at points south of Elephant Butte Reservoir in New Mexico, USGS streamflow data were replaced with streamflow data from the Colorado Division of Water Resources (CODWR) or the International Boundary and Water Commission (IBWC) (CODWR, 2019; IBWC, 2019). The alternative (to USGS) data were used either because the USGS streamgage was discontinued or its operation was taken over by CODWR or IBWC, and two additional streamgages (0628222 and 0651222) were added in Colorado. It is important to note that some CODWR data may have undergone minor revisions from the time the data were obtained in 2017. The sites for which USGS data were either replaced or added for streamgaging points in the URGBPRMS model are listed in table 2.

\section{Selection of Near-Native Subbasins}

One goal of this modeling effort was to create a PRMS model that could adequately simulate near-native landscape hydrologic and streamflow conditions in the Upper Rio Grande Basin. To meet this goal, a set of streamgages was needed at sites that had minimal upstream influences of reservoirs or diversions. A total of 92 USGS streamgages were identified within the basin that had at least 5 years of data since 1980, a contributing area greater than $30 \mathrm{mi}^{2}$, and either perennial flows or annual peak flows greater than 1,000 cubic feet per second $\left(\mathrm{ft}^{3} / \mathrm{s}\right)$. All basins were analyzed by inspection of aerial imagery above each streamgage location. Data from basins with reservoirs or substantial surface-water withdrawal infrastructure evident (that is, those from which it was likely that greater than 5 percent of total reach flow would be diverted) were removed from the analysis, leaving 25 streamgages for consideration. Agency personnel from USGS, NMOSE/ISC, CODWR, and the U.S. Forest Service with firsthand knowledge of the subject streamgages and affiliated basins were contacted regarding existence of reservoirs and extent of diversions, leading to the removal of all but 11 streamgages from consideration. Field reconnaissance and rough calculation of potential diversion capacity was conducted for two (of the 11) sites where assessment of diversion infrastructure with aerial imagery was inconclusive; both sites showed evidence of substantial diversion capacity, and thus both were removed from consideration. A total of nine streamgages (table 3; fig.2) were selected that met all criteria for near-native streamflow conditions with sufficient streamflow data for model calibration.

Selection of these nine streamgages with near-native flow conditions was verified by using the GAGES database (Falcone and others, 2010), a national effort to characterize basin and streamflow features indicative of natural streamflow. The national effort compiled and assessed an extensive list of basin and site characteristics for a total of 6,785 USGS streamgages with at least 20 years of complete-year flow record from the 1950-2007 period. Streamgages were given disturbance index scores of 0 to 8 (representing no disturbance or the 1st, 20th, 40th, 60th, 80th, 90th, 95th, and 98th percentiles of assessed streamgages, respectively) for each variable. For purposes of this study, four variables were selected for inclusion in the disturbance index: (1) density of major dams; (2) change in reservoir storage, 1950 to 2006; (3) percent of stream length coded as "Canal," "Ditch," "Pipeline," or "Artificial Path" in the National Hydrography Dataset Plus; and (4) fragmentation index of "undeveloped" (nonurban, nonagriculture) land in the subbasin. Four of the nine selected subbasins were included in the GAGES database. Each subbasin received very low disturbance scores (disturbance index of 0 or 1 for every variable except at Arroyo Chico [streamgage 08340500], and mean disturbance index of 1 or less), which confirmed their selection individually and validated the method used to identify near-native subbasins in this study.

\section{Selection of Parameters for PRMS Calibration}

Selection of the most appropriate parameters is critical to a successful calibration process. Several important factors warrant consideration in parameter selection. First, it is important to understand which processes and parameters are most influential on hydrologic model simulation results and how they vary within the basin. Basin hydrologic processes, such as infiltration, snowmelt runoff, and overland flow, vary according to spatially and temporally varying combinations of land surface and climatological conditions. For example, streamflow from a cold mountainous basin may reflect a high dependency on snowmelt processes, whereas streamflow from a warmer lowland basin may reflect greater dependency on evapotranspiration processes. As such, the most influential parameters may also be expected to change depending on location within the basin. Second, it is important to know if site-specific data are available to parameterize the model. Distributed hydrologic models typically have many adjustable input parameters that enable accurate simulation of hydrologic response to a variety of conditions in different areas, but data sources are not normally available for all parameters (Beven, 2002; Kirchner, 2006). Finally, it is important to understand how model parameters interact. Because of such interaction, several different combinations of adjustable input parameters, some of which may be unrealistic (that is, "get the right result for the wrong reasons"), may produce similar model performance, a situation known as "equifinality" (Beven, 2002; Kirchner, 2006). 
Table 2. List of all streamgages included in the Upper Rio Grande Basin Precipitation-Runoff Modeling System (URGB-PRMS) model, including streamgages where data were replaced or added for specific streamgaging points in the model.

[CO, Colorado; NM, New Mexico; TX, Texas; ID, Identification; CODWR, Colorado Division of Water Resources; USGS, U.S. Geological Survey; IBWC, International Boundary and Water Commission]

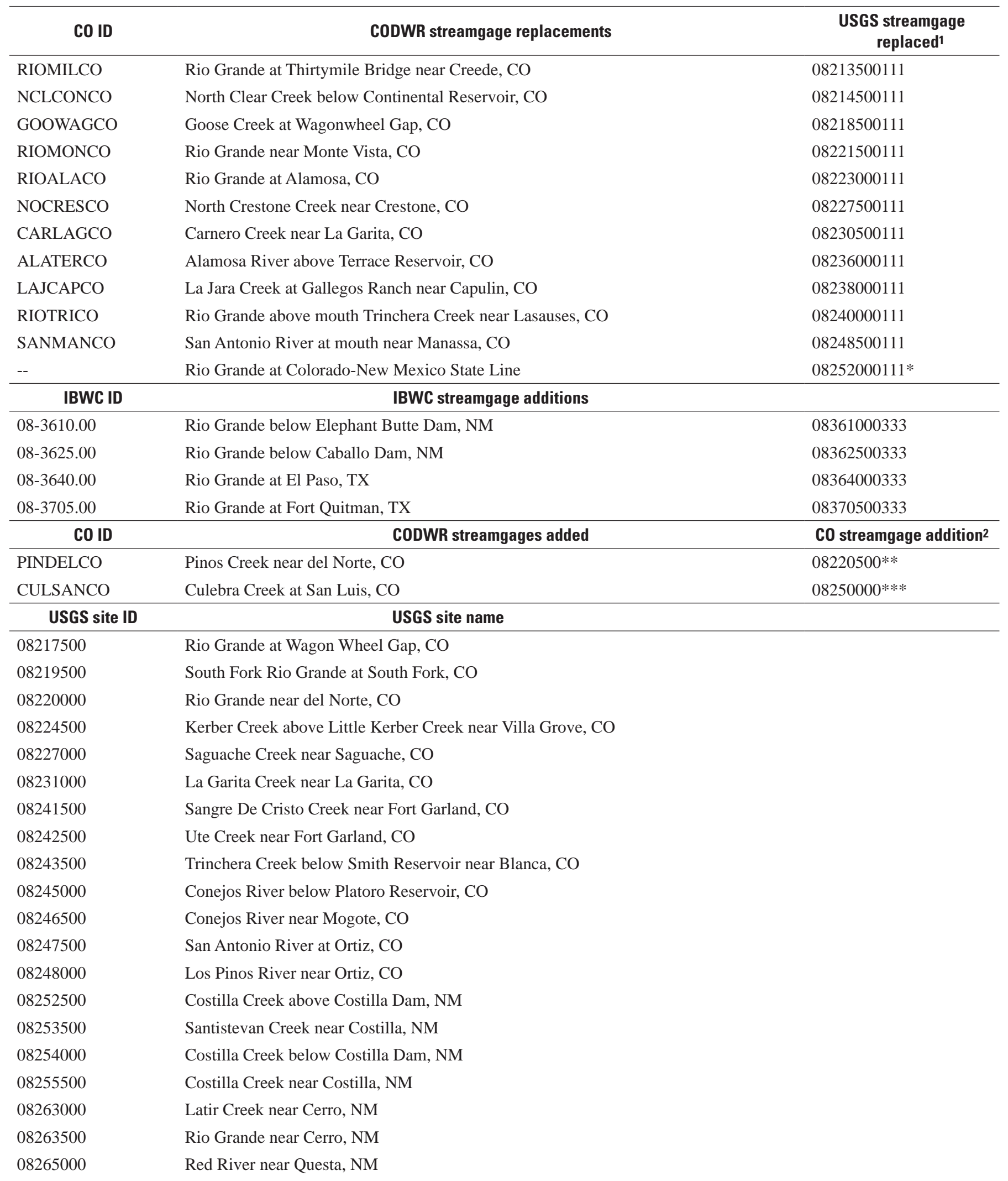


Table 2. List of all streamgages included in the Upper Rio Grande Basin Precipitation-Runoff Modeling System (URGB-PRMS) model, including streamgages where data were replaced or added for specific streamgaging points in the model.-Continued

[CO, Colorado; NM, New Mexico; TX, Texas; ID, Identification; CODWR, Colorado Division of Water Resources; USGS, U.S. Geological Survey; IBWC, International Boundary and Water Commission]

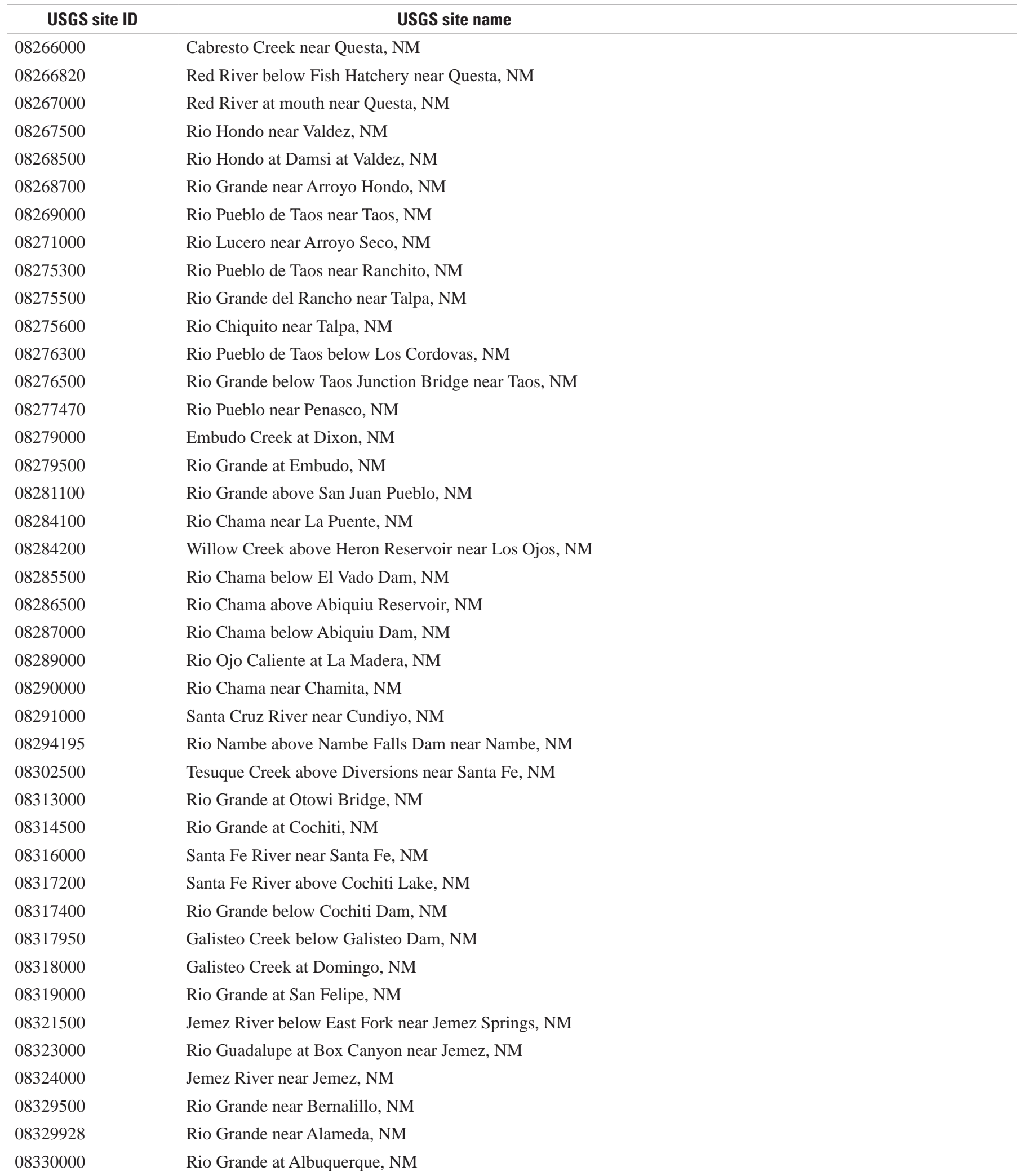




\section{Application of PRMS To Simulate Near-Native Streamflow, Upper Rio Grande Basin}

Table 2. List of all streamgages included in the Upper Rio Grande Basin Precipitation-Runoff Modeling System (URGB-PRMS) model, including streamgages where data were replaced or added for specific streamgaging points in the model.-Continued

[CO, Colorado; NM, New Mexico; TX, Texas; ID, Identification; CODWR, Colorado Division of Water Resources; USGS, U.S. Geological Survey; IBWC, International Boundary and Water Commission]

\begin{tabular}{ll}
\hline \multicolumn{1}{c}{ USGS site ID } & \multicolumn{1}{c}{ USGS site name } \\
\hline 08330600 & Tijeras Arroyo near Albuquerque, NM \\
08330875 & Rio Grande at Isleta Lakes near Isleta, NM \\
08334000 & Rio Puerco above Arroyo Chico near Guadalupe, NM \\
08340500 & Arroyo Chico near Guadalupe, NM \\
08341500 & Bluewater Creek below Bluewater Dam, NM \\
08343000 & Rio San Jose at Grants, NM \\
08343100 & Grants Canyon at Grants, NM \\
08351500 & Rio San Jose at Correo, NM \\
08352500 & Rio Puerco at Rio Puerco, NM \\
08353000 & Rio Puerco near Bernardo, NM \\
08354000 & Rio Salado near San Acacia, NM \\
08477000 & Mimbres River near Mimbres, NM \\
08477110 & Mimbres River at Mimbres, NM \\
\hline
\end{tabular}

1Streamgages taken over by the CODWR end in 111, and streamgages maintained by IBWC end in 333.

*Streamflow data for 08252000 replaced with 08251500 Rio Grande River near Lobatos, CO, data.

2Former USGS streamgages added, now CODWR streamgage 0628222** and 0651222***.

An analysis to determine the strength of input-parameter influence on model-output response is called a sensitivity analysis. Sensitivity analyses are conducted for a specific model and study area to focus model development and calibration efforts on the most influential parameters (Moriasi and others, 2015; Yuan and others, 2015). Sensitivity analyses can focus model parameterization efforts on the most influential parameters, identify important interactions that may influence calibration strategies, and reduce the potential for unrealistic calibration results through equifinality.

\section{Fourier Amplitude Sensitivity Test (FAST)}

A national-level sensitivity analysis was performed to better understand interactions between PRMS calibration parameters and process variables (Markstrom and others, 2016). This analysis used a Fourier amplitude sensitivity test (FAST) to analyze 110,000 subregions, or HRUs, of the conterminous United States for an 11-year period (1990-2000). The FAST analysis used seven fundamental daily streamflow statistics, in which each statistic represented nonredundant information on hydrologic response (Archfield and others, 2014). Analysis by Markstrom and others (2016), as well as this report, focuses on three of the seven statistics: mean daily streamflow (representative of total daily streamflow volume), coefficient of variation of daily flow (representative of streamflow "flashiness"), and autoregressive lag-1 correlation coefficient of daily flow (representative of day-to-day timing of flow).

The sensitivity analysis described by Markstrom and others (2016) focused on eight of the PRMS hydrologic-process output variables: snowmelt, surface runoff, infiltration, soil moisture, evapotranspiration, interflow, base flow, and streamflow. This sensitivity analysis allowed for a better understanding of key hydrologic processes for an HRU and the dominant parameters that affect each key process to improve runoff modeling within a study area (Markstrom and others, 2016). The FAST results have shown that on average (of 110,000 HRUs in the conterminous United States), 90 percent of the parameter sensitivity to key hydrologic processes in a given HRU usually comes from just 2 to 9 parameters, which is a small subset of the 36 standard calibration parameters. Using the sensitivity analysis to selectively reduce the number of calibration parameters improves understanding of PRMS process-parameter interactions and reduces potential for equifinality by reducing the number of parameters needed to be adjusted to make an accurate calibration. 
Table 3. Streamgages selected to represent near-native streamflow conditions in the Upper Rio Grande Basin.

[ID, identification; CO, Colorado; NM, New Mexico; USGS, U.S. Geological Survey; CODWR, Colorado Division of Water Resources]

\begin{tabular}{ll}
\hline \multicolumn{1}{c}{ Site ID } & \multicolumn{1}{c}{ Near-native subbasins } \\
\hline 0822500 & Kerber Creek above Little Kerber Creek near Villa Grove, CO \\
10628222 & Pinos Creek near del Norte, CO \\
208236000111 & Alamosa River above Terrace Reservoir, CO \\
08269000 & Rio Pueblo de Taos near Taos, NM \\
08275500 & Rio Grande del Rancho near Talpa, NM \\
08321500 & Jemez River below East Fork near Jemez Springs, NM \\
08334000 & Rio Puerco above Arroyo Chico near Guadalupe, NM \\
08340500 & Arroyo Chico near Guadalupe, NM \\
08354000 & Rio Salado near San Acacia, NM \\
\hline
\end{tabular}

1Former USGS streamgage (08220500), now CODWR streamgage 0628222.

${ }^{2}$ Streamgage taken over by the CODWR ends in 111.

Due to the size of the FAST output for the conterminous United States, a large amount of data manipulation and analysis is needed to parse and analyze the data for a small study area. As part of a prior study by Douglas-Mankin and Moeser (2019), a platform was created to provide a quasi-graphical user interface to easily query the FAST data by region, HRU, groupings of HRUs, specific aspects of the flow regime, and groupings of flow-regime aspects. This procedure allows quick, site-specific determination of the key parameters and processes and their associated influence on various aspects of the flow regime, which permits a more informed, quicker calibration process in which only key processes and affiliated parameters are optimized for an area.
The parsed FAST results for the Upper Rio Grande Basin were analyzed in the same manner as described by DouglasMankin and Moeser (2019). A calibration plan unique to each of the nine near-native subbasins was developed from a determination of which hydrologic processes and parameters exhibited the greatest influence in simulating streamflow volume, flashiness, and timing. A complete list of parameters selected for calibration are shown in table 4 . 
Table 4. Procedure used in the calibration of solar radiation and potential evapotranspiration in 133 subareas (steps 1 and 2 ), and for calibration of streamflow (steps 3-5) in the nine near-native subbasins using Luca software (Hay and Umemoto, 2006).

[dday, degree-day; NRMSE, normalized root mean square error; ${ }^{\circ}$ F, degrees Fahrenheit]

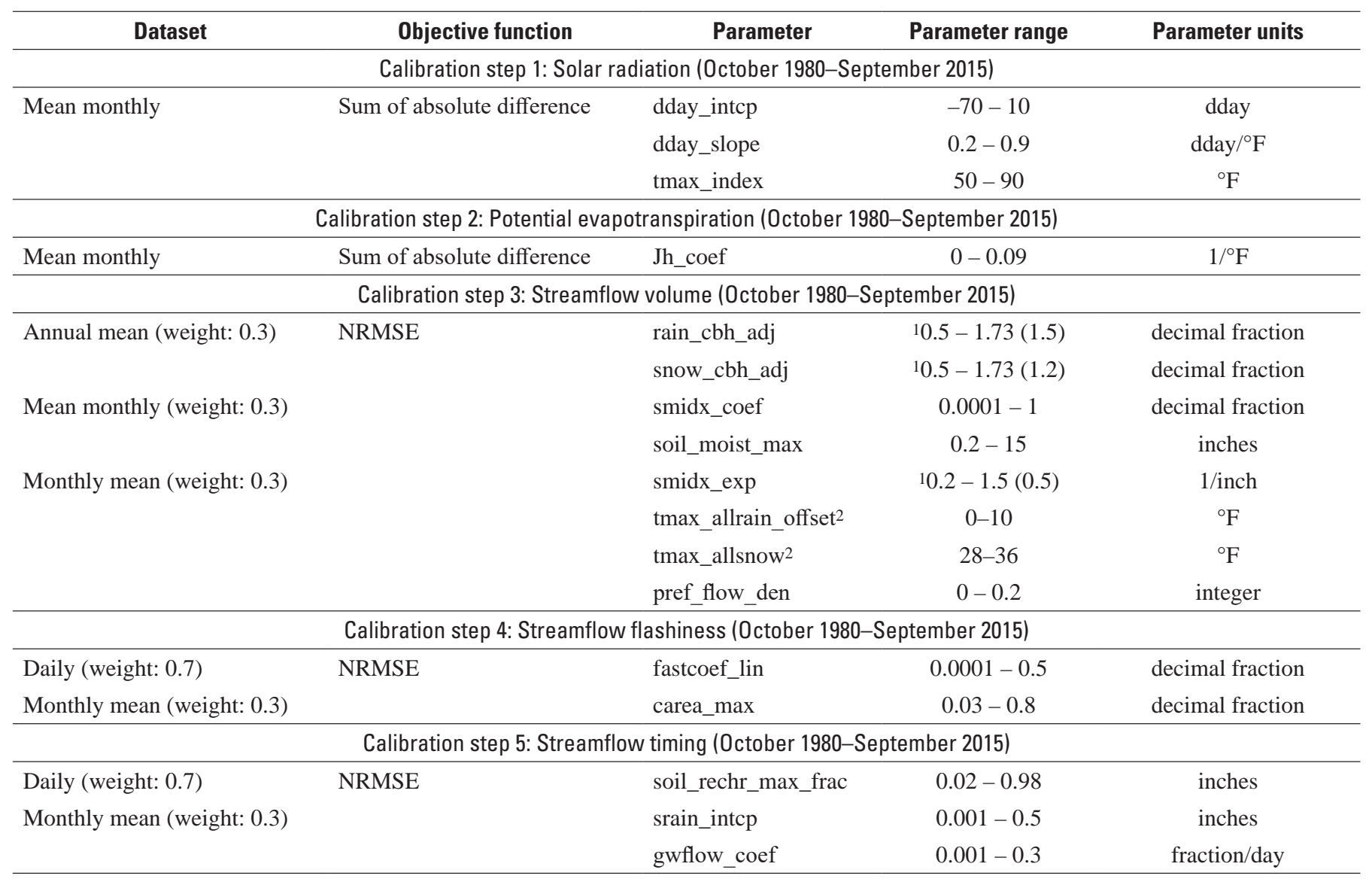

1Upper bound for Rio Salado.

2Kerber Creek, Alamosa River, and Rio Salado do not include tmax_allrain_offset and tmax_allsnow in calibration.

\section{Model Calibration}

Each near-native subbasin was calibrated in a step-wise, multiple-objective manner outlined in Markstrom and others (2015) that involved calibration of streamflow volume, flashiness, and timing from a parameter list developed from the FAST results. First, however, solar radiation (SR) and potential evapotranspiration (PET) were calibrated for all hydrologic response units (HRUs) within the model domain before the calibration of streamflow in just the near-native subbasins. All five steps used the Luca software ([Let us calibrate]; Hay and Umemoto, 2006; Hay and others, 2006).

\section{Step 1 \& 2: Solar Radiation, Potential Evapotranspiration}

The Upper Rio Grande Basin was divided into 133 subareas for calibration of SR and PET (fig. 3). The subareas were determined on the basis of location, elevation, and vegetation. Using the Luca software, SR and PET parameters were calibrated in a two-step process for the HRUs in each subarea (table 4); parameters dday_intcp, dday_slope, and tmax index were used in the calibration of SR in the first step, and the parameter jh_coef was used in the calibration of PET in the second step. Simulated basin shortwave radiation (basin_swrad) and basin PET (basin_potet), from the 1980-2015 period was calibrated to measured historical data provided in the Normal Incident Solar Radiation Atlas and the Mean Monthly Evaporation Atlas (Farnsworth and others, 1982) obtained from the USGS Geo Data Portal (Blodgett and others, 2011). Table 4 outlines the calibration process, lists the format of observed datasets, objective functions and parameters calibrated in each step, the range of values a parameter can assume, and units of each parameter. 


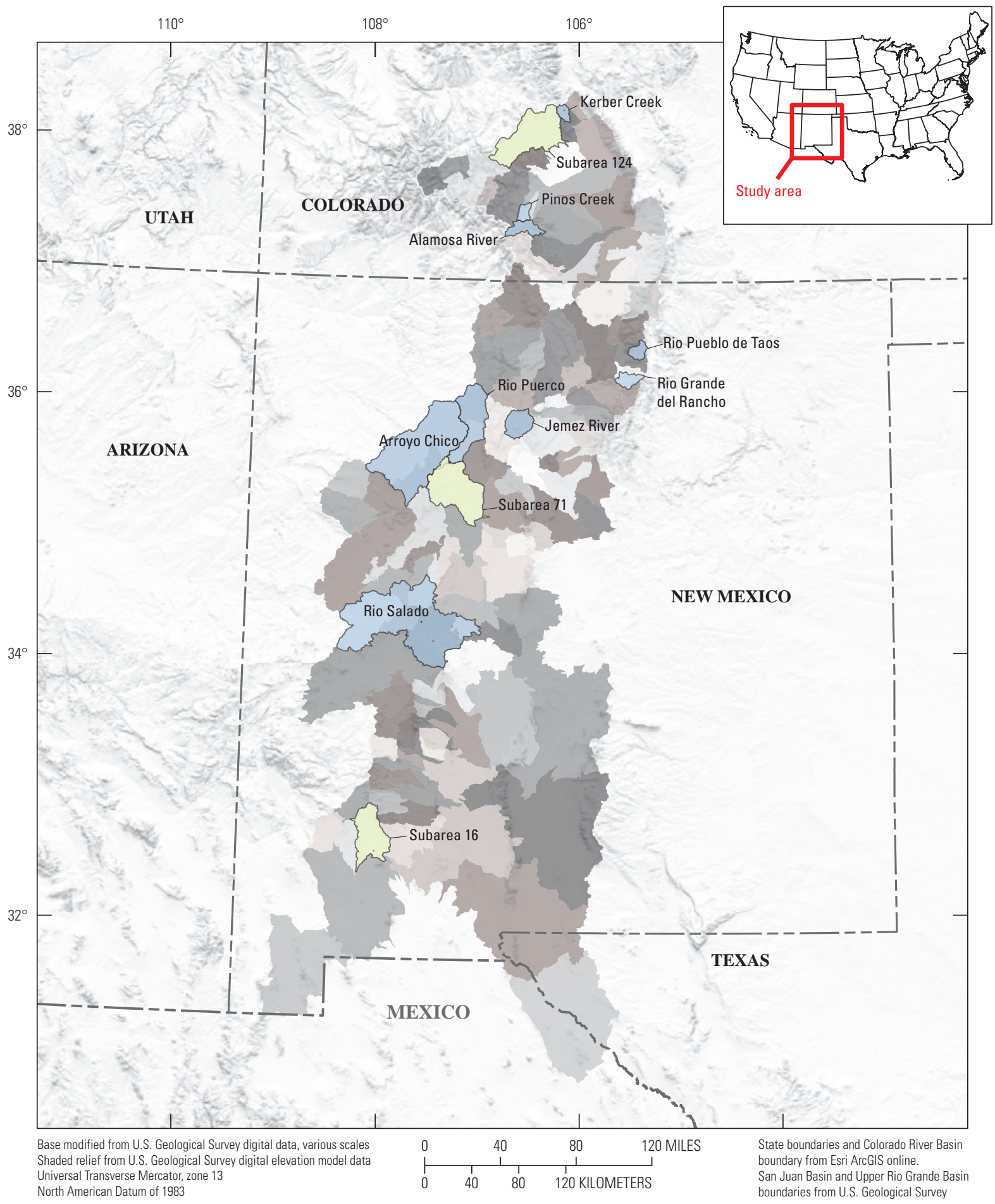

\section{EXPLANATION}

Simulated subareas

Near-native subbasin

Figure 3. Subareas used in the calibration of solar radiation and potential evapotranspiration (shaded gray-white), and selected subareas [subarea 16 , subarea 71 , subarea 124] and near-native subbasins simulated in calibration results. 


\section{Step 3 - 5: Streamflow}

Parameters associated with streamflow volume, timing, and flashiness were calibrated in each of the nine near-native subbasins (table 4). The calibration process consisted of three rounds with three steps within each round. Calibration of streamflow volume, timing, and flashiness were each one of the three steps, and calibration of parameters in each step was repeated three times (3 rounds) within Luca for the time period October 1980 through December 2015. The near-native subbasins selected for calibration, and the period of record and summary statistics for each subbasin, are listed in table 5. A total of 13 parameters were calibrated in each subbasin, except for the Alamosa River, Kerber Creek, and Rio Salado subbasins, in which tmax_allrain_offset and tmax_allsnow were not used in streamflow calibration because the sensitivity analysis indicated that these parameters did not substantially affect streamflow in these subbasins.

Simulated streamflow for a specific near-native subbasin (basin_cfs) was calibrated to USGS streamgage data (or CODWR data for replacement streamgages). Four of the nine subbasins had complete streamgage datasets, and the remaining five sites had incomplete streamgage data (that is, no data were available for parts of the time period from 1980 to 2015). In these cases, only those time periods with streamgage data were used in calibration.

\section{Parameter Distribution}

A package of scripts was developed to distribute calibrated parameters from the nine near-native subbasins to the rest of the uncalibrated HRUs in the model domain. The scripts used multiple linear regression, inverse distance weighted (IDW) interpolation, and a priori knowledge of calibrated parameter values from the NHM database to assign a value to noncalibrated HRUs (areas not within the nine nearnative subbasins).

Adjustment factors from the 13 parameters used in the calibration of streamflow (table 4) within the near-native subbasins were distributed to noncalibrated HRUs to represent near-native streamflow conditions at those HRUs falling outside of the near-native basins. An adjustment factor is defined as the difference between the postcalibration value and the precalibration value (initial NHM value). Once the adjustment factors are calculated for each near-native subbasin for each parameter, these values are then distributed by using IDW and added to each noncalibrated HRU's initial value (fig. 4).

The user defines up to three potential parameter dependencies for each parameter on the basis of unique HRU characteristics that include soil type, canopy type, canopy density, elevation, and slope. The parameter dependencies are the independent variables used in the regression equations generated at each near-native subbasin. The scripts then generate unique linear regression equations at each near-native subbasin for each parameter adjustment factor (and for each month for parameters indexed by month) on the basis of the user-defined characteristic(s). The equations for each parameter at each subbasin are then weighted and applied on the basis of an inverse distance weighting algorithm if the subbasin falls within a user-defined neighborhood. The adjustment factor is then attached to the value at HRUx (where HRUx is the location that a parameter is being interpolated to) by a simple addition or subtraction. A simplified example of this procedure is shown in figure 4.

Prior to running distribution scripts, several user-defined values were assigned. The values include upper and lower bounds for parameters, thresholds for adjustment factors, a neighborhood distance, inverse distance weighting power, and parameter dependencies.

Parameter bounds are the maximum and minimum values that a specific parameter can assume. These are the same ranges as those used for the 13 parameters in the calibration of streamflow (table 4). Adjustment factor thresholds are the maximum and minimum amounts that can be added to or subtracted from the initial precalibrated parameter value for the respective HRU. Initial adjustment factor thresholds for each parameter were determined by dividing the difference in the maximum and minimum parameter bound in half. For example, lower and upper bounds for the parameter srain_intcp (summer rain interception) were 0.001 and 0.50 , respectively. Performing the calculation for the adjustment factor threshold $[(0.50-0.001) / 2)]$ would result in adjustment factor bounds of \pm 0.25 for parameter srain_intcp. However, adjustment factor thresholds were uniquely adjusted for each parameter and generalized region in the basin, as described in the following sections (Headwaters, Upper Rio Grande Section, Middle Rio Grande Section, Lower Rio Grande Section).

Values provided for the neighborhood and power function attached to the IDW scheme determine which HRUs will be given interpolated parameters and the influence that each subbasin will have on an interpolated value. The value given for the neighborhood is the maximum distance from the centroid of a near-native subbasin to the centroid of the HRU where a parameter will be interpolated. As seen in figure 4, subbasin 'b' was not used in the distribution scheme because it fell outside of the defined neighborhood. The power, or value of the exponent on the inverse distance weighting equation (' $\mathrm{P}$ ' in fig. 4) is used in computing the weight, or influence, that each of the near-native subbasins will have on a distributed parameter. A higher value for the exponent will increase the influence of distant near-native subbasins.

To exert greater control on the influence of each nearnative subbasin on parameter distribution, four sections within the model domain with relatively similar climate and streamflow patterns were used. The neighborhood value was adjusted in these sections to either increase or decrease the influence of specific near-native subbasins on parameters distributed to HRUs in the section. These sections correspond to the regions described in the study area description (fig. 2) of climate variation in the basin: (1) the headwaters, (2) Upper Rio Grande, (3) Middle Rio Grande, and (4) Lower Rio Grande. 
Table 5. Subbasins used for calibration and validation, periods of record, and summary statistics for nine near-native subbasins of the Upper Rio Grande Basin Precipitation-Runoff Modeling System model.

[NSE, Nash-Sutcliffe efficiency; R², coefficient of determination; \%, percent; CO, Colorado; NM, New Mexico]

\begin{tabular}{|c|c|c|c|c|c|c|c|c|c|c|}
\hline \multirow[t]{2}{*}{ Calibrated subbasin } & \multirow{2}{*}{ Period of record } & \multicolumn{3}{|c|}{ Initial values } & \multicolumn{3}{|c|}{ Calibrated values } & \multicolumn{3}{|c|}{$\begin{array}{l}\text { Validation of parameter } \\
\text { translation }\end{array}$} \\
\hline & & NSE & $\mathbf{R}^{2}$ & Bias $(\%)$ & NSE & $\mathbf{R}^{2}$ & Bias (\%) & NSE & $\mathbf{R}^{2}$ & Bias $(\%)$ \\
\hline $\begin{array}{l}\text { Kerber Creek above Little Kerber Creek } \\
\text { near Villa Grove, CO }\end{array}$ & $\begin{array}{l}(10 / 1980-9 / 1982) \\
(10 / 1998-9 / 2007)\end{array}$ & 0.07 & 0.26 & -50.0 & 0.68 & 0.69 & -4.4 & -- & -- & -- \\
\hline Pinos Creek near del Norte, CO & $(10 / 1980-12 / 2015)$ & 0.47 & 0.73 & 27.2 & 0.82 & 0.83 & -2.8 & 0.62 & 0.76 & 16.6 \\
\hline Alamosa River above Terrace Reservoir, CO & $(10 / 1980-12 / 2015)$ & 0.61 & 0.70 & -34.8 & 0.85 & 0.85 & -1.4 & -- & -- & -- \\
\hline Rio Pueblo de Taos near Taos, NM & $(10 / 1980-12 / 2015)$ & 0.06 & 0.38 & -70.8 & 0.81 & 0.81 & -0.1 & 0.54 & 0.68 & 2.4 \\
\hline Rio Grande del Rancho near Talpa, NM & $\begin{array}{l}(10 / 1980-9 / 1982) \\
(10 / 1985-12 / 2015)\end{array}$ & -0.36 & 0.18 & 107.2 & 0.78 & 0.79 & -1.2 & -- & -- & -- \\
\hline $\begin{array}{l}\text { Jemez River below East Fork near Jemez } \\
\text { Springs, NM }\end{array}$ & $(8 / 1981-12 / 1990)$ & -0.35 & 0.00 & 67.0 & 0.85 & 0.86 & -6.1 & -- & -- & -- \\
\hline $\begin{array}{l}\text { Rio Puerco above Arroyo Chico near } \\
\text { Guadalupe, NM }\end{array}$ & $(10 / 1980-10 / 2014)$ & -2.96 & 0.16 & 189.0 & 0.47 & 0.47 & 4.0 & 0.09 & 0.20 & -10.1 \\
\hline Arroyo Chico near Guadalupe, NM & $\begin{array}{l}(10 / 1980-9 / 1986) \\
(10 / 2005-9 / 2014)\end{array}$ & -12.48 & 0.23 & 259.4 & 0.60 & 0.63 & 1.3 & -- & -- & -- \\
\hline Rio Salado near San Acacia, NM & $(10 / 1980-9 / 1984)$ & -18.96 & 0.21 & 909.3 & 0.68 & 0.70 & 30.8 & -- & -- & -- \\
\hline
\end{tabular}




\section{Interpolation example: adjustment factors}

Adjustment factor $=($ postcalibration value $)-($ precalibration NHM value $)$

User-defined information for parameter ' $y$ ':

(1) Parameter ' $y$ ' in this example is related to one HRU characteristic - Elevation

(2) Relation between parameter ' $y$ ' and elevation are potentially unique in each basin

(3) Parameter ' $y$ ' maintains similar population dynamics over space but loses any similarities after 4.5 miles (mi)

(4) Relations change each month

\section{Initial Values}

Neighborhood radius of $4.50 \mathrm{mi}$ (each grid is given a value of $1 \mathrm{mi})$

- Power (P) of 2 (inverse distance squared)

- Elevation of estimated HRU $(\square)=1,000$ feet

- Precalibration value $\mathrm{HRU} \mathrm{x}=7$

Native subbasin 'a' adjustment factor $\quad \mathrm{y}^{*} \mathrm{a}=0.05 \times$ elevation $+5 \quad\left(\mathrm{y}^{*} \mathrm{a}=0.005 \times 1,000+5=\underline{10}\right)$

Native subbasin ' $b$ ' adjustment factor $y^{*} b=N A$-it is outside the search radius

Native subbasin ' $c$ ' adjustment factor $\mathrm{y}^{*} \mathrm{c}=0.06 \times$ elevation $+3 \quad\left(\mathrm{y}^{*} \mathrm{c}=0.006 \times 1,000+3=\underline{9}\right)$

Native subbasin ' $d$ ' adjustment factor $y^{*} d=0.03 \times$ elevation $+7 \quad\left(y^{*} d=0.003 \times 1,000+7=\underline{10}\right)$

$y^{*} x($ January $)=\frac{\frac{10}{2.5^{P}}+\frac{9}{1.5^{P}}+\frac{10}{2.1^{P}}}{\frac{1}{2.5^{P}+\frac{1}{1.5^{P}}+\frac{1}{2.1^{P}}}}=9.47+$ precalibration value $(H R U x)=16.47$

${ }^{*}$ Regression equations ( $y^{*}$ native subbasin) are created at each subbasin for each parameter. The user defines up to three potential dependencies for each parameter based upon unique HRU characteristics:

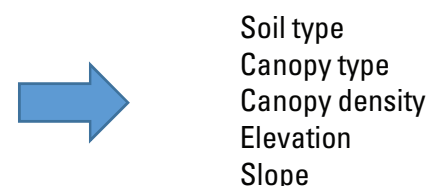

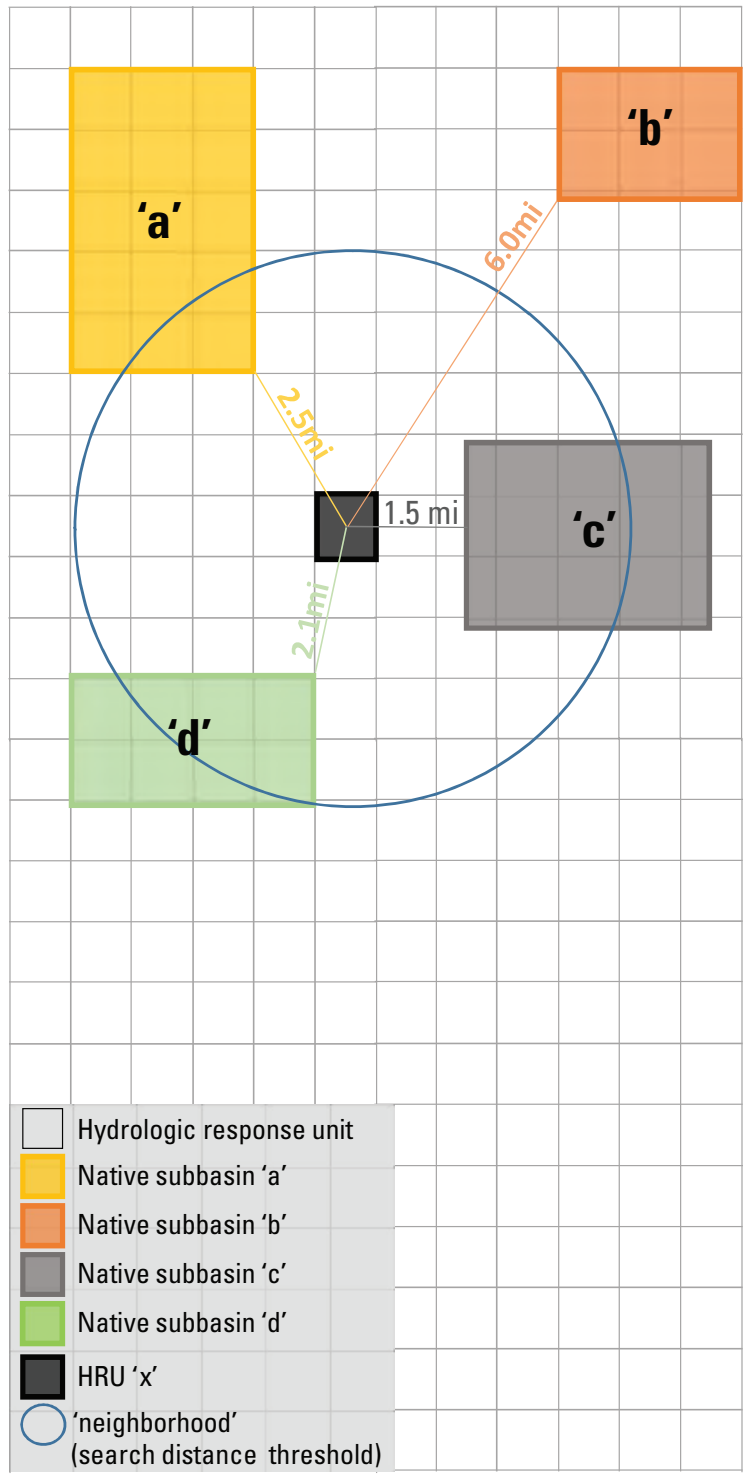

Figure 4. Parameter interpolation example in an idealized Precipitation-Runoff Modeling System (PRMS) domain (National Hydrologic Model [NHM]; Hydrologic Response Unit [HRU]; Not applicable [NA]). 
The parameter distribution scripts were run for each of these sections with the IDW exponent set to 2 (inverse distance square weighting), and the upper and lower parameter bounds remained unchanged for all runs.

\section{Headwaters Section}

The headwaters section of the Upper Rio Grande Basin includes HRUs north of the Colorado-New Mexico State line (fig. 2). Streamflow in this area is derived primarily from melting of the seasonal snowpack at high elevations. The neighborhood value for the section was set to 186 miles, which included all near-native subbasins except the Rio Salado to be used in the computation of distributed parameter values to HRUs in the region. Near-native subbasins in this section with the most influence on parameter distribution with the specified neighborhood included Kerber Creek, Pinos Creek, Alamosa River, Rio Pueblo de Taos, and Rio Grande del Rancho (fig. 3).

Starting with the initial set of adjustment factor thresholds, the parameter distribution script was run for the headwaters section, and regression statistics for each parameter regression in each near-native subbasin were examined. Adjustment factor thresholds and parameter dependencies were modified, and parameters were kept if regression statistics improved with modifications. The final set of parameter dependencies and adjustment factor bounds used in the distribution script for the headwaters section are listed in table 6 . The parameter distribution was then validated by rerunning the final parameter distribution methodology for the section with one near-native subbasin removed (Pinos Creek). The HRUs within the removed subbasin (Pinos Creek) were then considered nonnative and parameter values were distributed to them. Statistics were then compared within this subbasin (Pinos Creek) of actual streamflow, estimated streamflow from the initial NHM parameter set, estimated streamflow from the calibrated parameter set, and estimated streamflow from the distributed value parameter set, with the goal of getting as close as possible to the calibrated parameter set (table 5). The above process was repeated until these values were optimized.

The same method was followed to distribute parameters to the remaining sections. However, the adjustment factor thresholds and dependencies from the previous section were used as initial values for the downstream region. For example, the script for the Upper Rio Grande section was run with the same final values used in the headwaters section, and those values were subsequently adjusted to optimize parameter and validation fits for the section. Likewise, initial values for the Middle Rio Grande section used final values from the Upper Rio Grande section, and initial values for the Lower Rio Grande section used final values from the Middle Rio Grande section.

\section{Upper Rio Grande Section}

Streamflow in the Upper Rio Grande section (fig. 2) is sustained by the melting of seasonal snowpack and summer monsoonal precipitation. Tributaries to the Rio Grande in this section are mostly perennial. The neighborhood value for the section was set to $87 \mathrm{mi}$, with the Rio Pueblo de Taos, Rio Grande del Rancho, and Jemez River near-native subbasins having greater influence on parameters in HRUs in the northern part of the Upper Rio Grande section. The Jemez River, Rio Puerco, and Arroyo Chico near-native subbasins influenced the parameter weighting more for HRUs in the southern part of the section. Final parameter adjustment factors and dependencies for the section are shown in table 7 . The parameter distribution was validated with the data for the Rio Pueblo de Taos near-native subbasin removed.

\section{Middle Rio Grande Section}

The Middle Rio Grande section (fig. 2) is more arid than the Upper Rio Grande section, and here the tributaries to the Rio Grande are either perennial or ephemeral. The neighborhood value for the section was set to $93 \mathrm{mi}$. The Jemez River, Rio Puerco, and Arroyo Chico exerted the most control on the distributed parameters in the northern part of the section. The Rio Salado subbasin had the greatest influence on parameters generated in the southern part of the section. Final parameter adjustment factors and dependencies for the Middle Rio Grande section are shown in table 8. Validation of the parameter distribution method for this section was performed by removing the Rio Puerco near-native subbasin.

\section{Lower Rio Grande Section}

The Lower Rio Grande section is an arid region in which most streams are ephemeral (fig. 2). The neighborhood value for the section was set to $242 \mathrm{mi}$. Jemez River, Rio Puerco, and Arroyo Chico (in the Middle Rio Grande) influenced the weighted distribution of parameters in the northern part of the Lower Rio Grande section, but overall, Rio Salado (in the Middle Rio Grande) had the most influence on parameters generated for this section. Final parameter adjustment factors and dependencies for the section are shown in table 9. Because there was no subbasin to validate the distributed parameters in this section, and the Rio Salado subbasin is most representative of streamflow in the section, the mean value for distributed parameters in the section were checked against the mean value for parameters for the Rio Salado near-native subbasin. 
Table 6. Values and parameter dependencies used in parameter distribution scripts for the headwaters section of the Upper Rio Grande Basin.

[HRU, hydrologic response unit]

\begin{tabular}{|c|c|c|c|c|c|c|c|c|}
\hline Section & Heachwaters & & & & & & & \\
\hline Neighborhood & 186 miles & & & & & & & \\
\hline Power & 2 & & & & & & & \\
\hline Basin_turn_off & 6 (Pinos Creek) & & & & & & & \\
\hline \multirow{2}{*}{ Parameter } & \multicolumn{2}{|c|}{ Adjustment factor thresholds } & \multicolumn{5}{|c|}{ Parameter dependencies } & \multirow{2}{*}{ Parameter units } \\
\hline & Lower bound & Upper bound & soil_type & canopy_type & canopy_density & elevation & slope & \\
\hline rain_cbh_adj & -0.5 & 0 & 0 & 0 & 0 & 1 & 0 & decimal fraction \\
\hline snow_cbh_adj & -0.5 & 0 & 0 & 0 & 0 & 1 & 0 & decimal fraction \\
\hline tmax_allrain_offset & -3 & 3 & 0 & 0 & 0 & 1 & 0 & ${ }^{\circ} \mathrm{F}$ \\
\hline tmax_allsnow & -3 & 3 & 0 & 0 & 0 & 1 & 0 & ${ }^{\circ} \mathrm{F}$ \\
\hline soil_moist_max & -3 & 3 & 1 & 0 & 0 & 1 & 1 & inches \\
\hline soil_rechr_max_fraction & -0.3 & 0.3 & 1 & 0 & 0 & 1 & 1 & inches \\
\hline smidx_exp & -0.9 & 0.9 & 1 & 0 & 0 & 1 & 1 & 1/inch \\
\hline smidx_coef & -0.005 & 0.01 & 1 & 0 & 0 & 1 & 1 & decimal fraction \\
\hline pref_flow_den & -0.08 & 0.08 & 1 & 0 & 0 & 1 & 1 & integer \\
\hline fastcoef_lin & -0.09 & 0.02 & 1 & 0 & 0 & 1 & 1 & decimal fraction \\
\hline carea_max & -0.04 & 0.04 & 1 & 0 & 0 & 1 & 1 & decimal fraction \\
\hline srain_intcp_fraction & -0.25 & 0.25 & 1 & 0 & 0 & 1 & 1 & inches \\
\hline gwflow_coef & -0.3 & 0.3 & 1 & 0 & 0 & 1 & 1 & fraction/day \\
\hline
\end{tabular}

Neighborhood: Maximum distance from the centroid of a native subbasin to the centroid of an HRU where a parameter will be interpolated.

Power: Value of the exponent on the inverse distance weighting equation.

Basin_turn_off: Basin used to validate parameter distribution method by allowing parameters to be interpolated to a native subbasin.

A value of 0 uses all subbasins in the specified neighborhood in interpolating parameters to other noncalibrated HRUs.

A value greater than 0 turns off a subbasin so that it is not used in parameter distribution, and new parameters are generated for HRUs in that that subbasin.

Parameter dependencies Independent variables in regressions generated for each parameter and subbasin ( $0=$ parameter is not used, $1=$ =parameter is used). 
Table 7. Values and parameter dependencies used in parameter distribution scripts for the Upper Rio Grande section of the Upper Rio Grande Basin.

[HRU, hydrologic response unit]

\begin{tabular}{|c|c|c|c|c|c|c|c|c|}
\hline Section & Upper Rio Gran & & & & & & & \\
\hline Neighborhood & 87 miles & & & & & & & \\
\hline Basin_turn_off & 7 (Rio Pueblo de & & & & & & & \\
\hline Parameter & Lower bound & Upper bound & soil_type & canopy_type & canopy_density & elevation & slope & Parameter units \\
\hline rain_cbh_adj & -0.6 & 0 & 0 & 0 & 0 & 1 & 0 & decimal fraction \\
\hline snow_cbh_adj & -0.6 & 0 & 0 & 0 & 0 & 1 & 0 & decimal fraction \\
\hline soil_moist_max & -2.5 & 3 & 1 & 0 & 0 & 1 & 1 & inches \\
\hline soil_rechr_max_fraction & -0.3 & 0.3 & 1 & 0 & 0 & 1 & 1 & inches \\
\hline smidx_exp & -0.4 & 0.4 & 1 & 0 & 0 & 1 & 0 & 1/inch \\
\hline smidx_coef & -0.0005 & 0.0005 & 1 & 0 & 0 & 1 & 1 & decimal fraction \\
\hline pref_flow_den & -0.08 & 0.08 & 1 & 0 & 0 & 1 & 1 & integer \\
\hline
\end{tabular}

Neighborhood: Maximum distance from the centroid of a native subbasin to the centroid of an HRU where a parameter will be interpolated.

Pover: Value of the exponent on the inverse distance weighting equation.

Basin_turn_off: Basin used to validate parameter distribution method by allowing parameters to be interpolated to a native subbasin.

A value of 0 uses all subbasins in the specified neighborhood in interpolating parameters to other noncalibrated HRUs.

A value greater than 0 turns off a subbasin so that it is not used in parameter distribution, and new parameters are generated for HRUs in that that subbasin.

Parameter dependencies Independent variables in regressions generated for each parameter and subbasin ( $0=$ parameter is not used, $1=$ =parameter is used). 
Table 8. Values and parameter dependencies used in parameter distribution scripts for the Middle Rio Grande section of the Upper Rio Grande Basin.

[HRU, hydrologic response unit]

\begin{tabular}{|c|c|c|c|c|c|c|c|c|}
\hline Section & \multicolumn{8}{|c|}{ Middlle Rio Grande } \\
\hline Neighborhood & \multicolumn{8}{|l|}{93 miles } \\
\hline Power & \multicolumn{8}{|l|}{2} \\
\hline Basin_turn_off & \multicolumn{8}{|l|}{8 (Rio Puerco) } \\
\hline \multirow{2}{*}{ Parameter } & \multicolumn{2}{|c|}{ Adjustment factor thresholds } & \multicolumn{5}{|c|}{ Parameter dependencies } & \multirow{2}{*}{ Parameter units } \\
\hline & Lower bound & Upper bound & soil_type & canopy_type & canopy_density & elevation & slope & \\
\hline rain_cbh_adj & -0.6 & 0 & 0 & 0 & 0 & 1 & 0 & decimal fraction \\
\hline snow_cbh_adj & -0.6 & 0 & 0 & 0 & 0 & 1 & 0 & decimal fraction \\
\hline tmax_allrain_offset & -3 & 3 & 0 & 0 & 0 & 1 & 0 & ${ }^{\circ} \mathrm{F}$ \\
\hline tmax_allsnow & -2 & 2 & 0 & 0 & 0 & 1 & 0 & ${ }^{\circ} \mathrm{F}$ \\
\hline soil_moist_max & -3 & 3.5 & 1 & 0 & 0 & 1 & 1 & inches \\
\hline soil_rechr_max_fraction & -0.3 & 0.3 & 1 & 0 & 0 & 1 & 1 & inches \\
\hline smidx_exp & -0.8 & 0.4 & 1 & 0 & 0 & 1 & 0 & 1/inch \\
\hline smidx_coef & -0.05 & 0.0003 & 1 & 0 & 0 & 1 & 1 & decimal fraction \\
\hline pref_flow_den & -0.08 & 0 & 1 & 0 & 0 & 1 & 1 & integer \\
\hline fastcoef_lin & -0.09 & 0.02 & 1 & 0 & 0 & 1 & 1 & decimal fraction \\
\hline carea_max & -0.06 & 0.01 & 1 & 0 & 0 & 1 & 1 & decimal fraction \\
\hline srain_intcp_fraction & -0.25 & 0.25 & 1 & 0 & 0 & 1 & 1 & inches \\
\hline gwflow_coef & -0.3 & 0 & 1 & 0 & 0 & 1 & 1 & fraction/day \\
\hline
\end{tabular}

Neighborhood: Maximum distance from the centroid of a native subbasin to the centroid of an HRU where a parameter will be interpolated.

Power: Value of the exponent on the inverse distance weighting equation.

Basin_turn_off: Basin used to validate parameter distribution method by allowing parameters to be interpolated to a native subbasin.

A value of 0 uses all subbasins in the specified neighborhood in interpolating parameters to other noncalibrated HRUs.

A value greater than 0 turns off a subbasin so that it is not used in parameter distribution, and new parameters are generated for HRUs in that that subbasin.

Parameter dependencies Independent variables in regressions generated for each parameter and subbasin ( $0=$ parameter is not used, $1=$ =parameter is used). 
Table 9. Values and parameter dependencies used in parameter distribution scripts for the Lower Rio Grande section of the Upper Rio Grande Basin.

[HRU, hydrologic response unit]

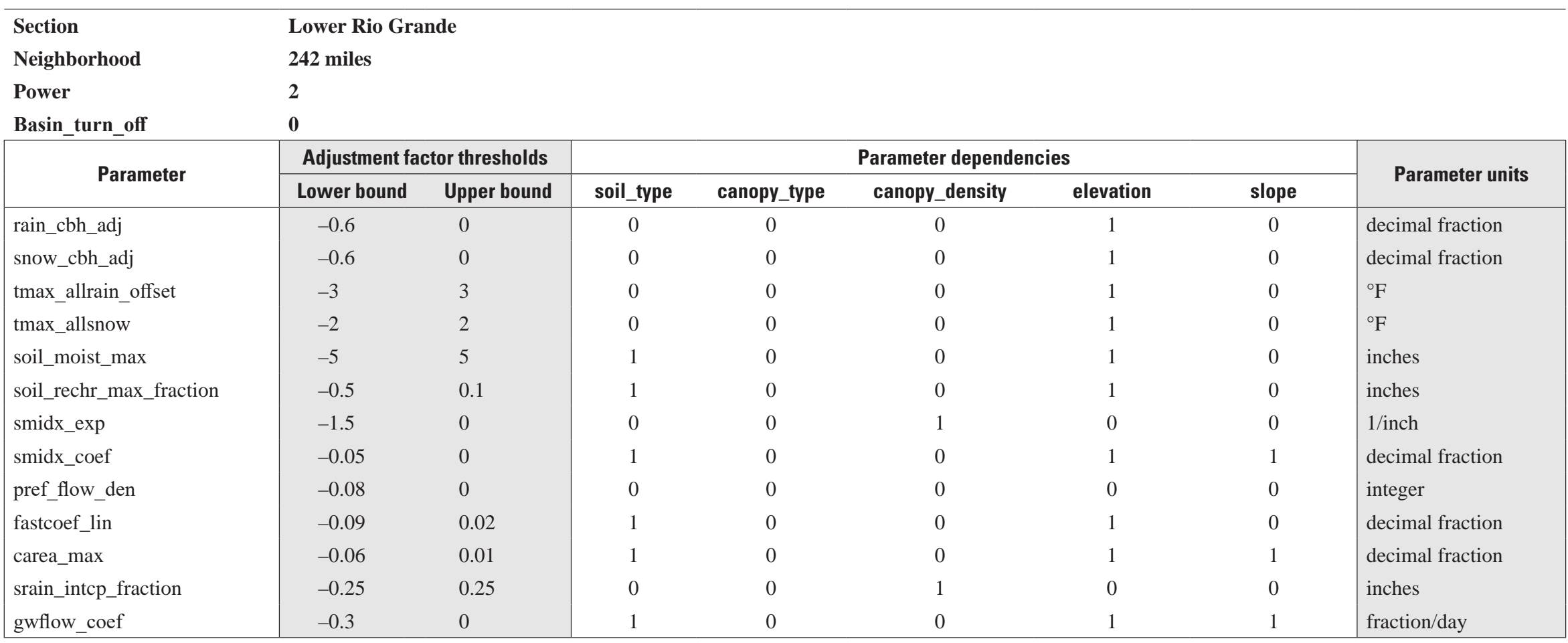

Neighborhood: Maximum distance from the centroid of a native subbasin to the centroid of an HRU where a parameter will be interpolated.

Pover: Value of the exponent on the inverse distance weighting equation.

Basin_turn_off: Basin used to validate parameter distribution method by allowing parameters to be interpolated to a native subbasin.

A value of 0 uses all subbasins in the specified neighborhood in interpolating parameters to other noncalibrated HRUs.

A value greater than 0 turns off a subbasin so that it is not used in parameter distribution, and new parameters are generated for HRUs in that that subbasin.

Parameter dependencies: Independent variables in regressions generated for each parameter and subbasin ( $0=$ parameter is not used, $1=$ parameter is used). 


\section{Model Calibration Results and Evaluation}

\section{Step 1: Solar Radiation and Potential Evapotranspiration}

Calibration results for SR and PET for three randomly selected subareas (fig. 3) in the upper (subarea 124), middle (subarea 71), and lower (subarea 16) parts of the basin and for the nine near-native subbasins are shown in figure 5 $(A-D)$. Calibration of mean monthly SR and PET resulted in improvements over NHM initial parameters, but initial NHM parameters were found to sufficiently represent SR and PET for simulated subareas (fig. 5A-B). Although HRUs that make up the near-native subbasins were grouped by subarea for the SR and PET calibration, simulated basin SR and PET for each near-native subbasin improved (fig. 5C-D). The greatest improvements in postcalibration simulated SR were seen in the Kerber Creek (08224500) and Rio Grande del Rancho (08275500) subbasins (fig. 5C), and the greatest improvements in PET were seen in the Rio Pueblo de Taos (08269000) and Arroyo Chico (08340500) subbasins (fig. 5D).

\section{Step 2: Streamflow}

Calibration of the URGB-PRMS model resulted in substantial improvements in streamflow simulations over simulations with initial NHM values, which demonstrates the value of model calibration at the local subbasin scale. Model performance both precalibration and postcalibration for each near-native subbasin was evaluated statistically and graphically. Model performance statistics were calculated on the basis of monthly total (sum of daily monthly values) simulated and observed streamflow values for each near-native subbasin (table 5).

Calibration results (table 5) were satisfactory (NashSutcliffe efficiency [NSE] $>0.5$, bias $< \pm 10$ percent; Harmel and others, 2018) or better for all subbasins except Rio Salado (08354000) (bias = about 31 percent). The median and range of daily cumulative streamflow for postcalibration simulations and observed values show good correlation, indicating that calibrated total streamflow volume is within an acceptable range of the gaged value for the Rio Puerco and near-native subbasins to the north (fig. 6).

Generally, the northerly, snowmelt-dominated subbasins performed better than the central and southern, monsoondominated subbasins. However, calibration results show the greatest improvement in the NSE and bias statistics over precalibrated NHM values in the southern monsoon-influenced subbasins Rio Puerco (08334000), Arroyo Chico (08340500), and Rio Salado (08354000) (table 5, fig. 2). Hydrographs of simulated (precalibration and postcalibration) and observed flows for each of the near-native subbasins show the differences in the seasonality of streamflow (fig. 6). Most of the streamflow in the six near-native subbasins from the Jemez River (08321500) and those to the north of the Jemez River occurs in the spring and early summer seasons (April-June), flow in the Rio Puerco (08334000) subbasin shows a bimodal seasonal pattern (April-June and August-September), and most flow in Arroyo Chico (08340500) and Rio Salado (08354000) subbasins occurs in mid-late summer (JulySeptember). The changes in seasonality and timing of streamflow explain some of the differences in model performance and the difficulty associated with calibrating subbasins with periods of no flow and "flashy" flows.

\section{Step 3: Parameter Distribution}

The parameter distribution method was validated by generating new parameters for three of the nine near-native subbasins (by not including these areas as near-native subbasins in the parameter distribution function). Observed streamflow at each of these three subbasins was then compared to estimated streamflow from the initial NHM parameter set, estimated streamflow from the calibrated parameter set, and estimated streamflow from the distributed value parameter set (table 5). The distribution method performed well for two subbasins in the northern part of the Upper Rio Grande Basin (Pinos Creek [08220500] and Rio Pueblo de Taos [08269000]), with satisfactory NSE ( $>0.50$ ) and very good to satisfactory overestimation bias (2.4 to 16.6 percent). Results were mixed for the centrally located subbasin Rio Puerco (08334000), with unsatisfactory NSE $(0.09)$ but good underestimation bias $(-10.1$ percent). Model performance for all subbasins after parameter distribution, however, is vastly improved over the initial NHM simulations: NSE improved from 0.47 to 0.62 for Pinos Creek, from 0.06 to 0.54 for Rio Pueblo de Taos, and from -2.96 to 0.09 for Rio Puerco, while bias improved from 27.2 percent to 16.6 percent for Pinos Creek, from -70.8 percent to 2.4 percent for Rio Pueblo de Taos, and from 189.0 percent to -10.1 percent for Rio Puerco (table 5). These results demonstrate that the PRMS model developed in this study with translated model parameters for the entire Upper Rio Grande Basin was successful in applying local information to improve model performance over that of the NHM, and that the new model is appropriate to use to simulate near-native conditions throughout the Upper Rio Grande Basin. 


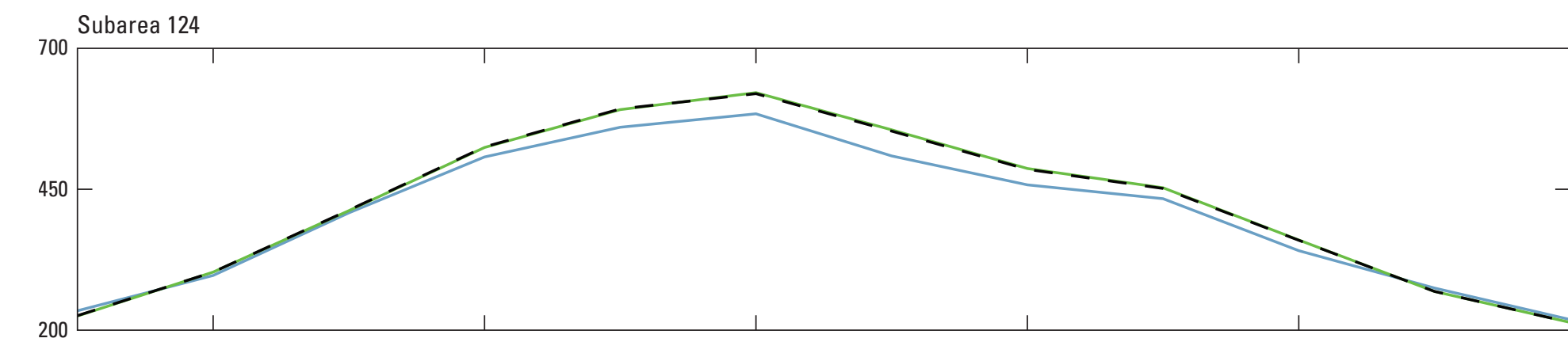

EXPLANATION

- Initial

Calibrated

- - - Observed

200
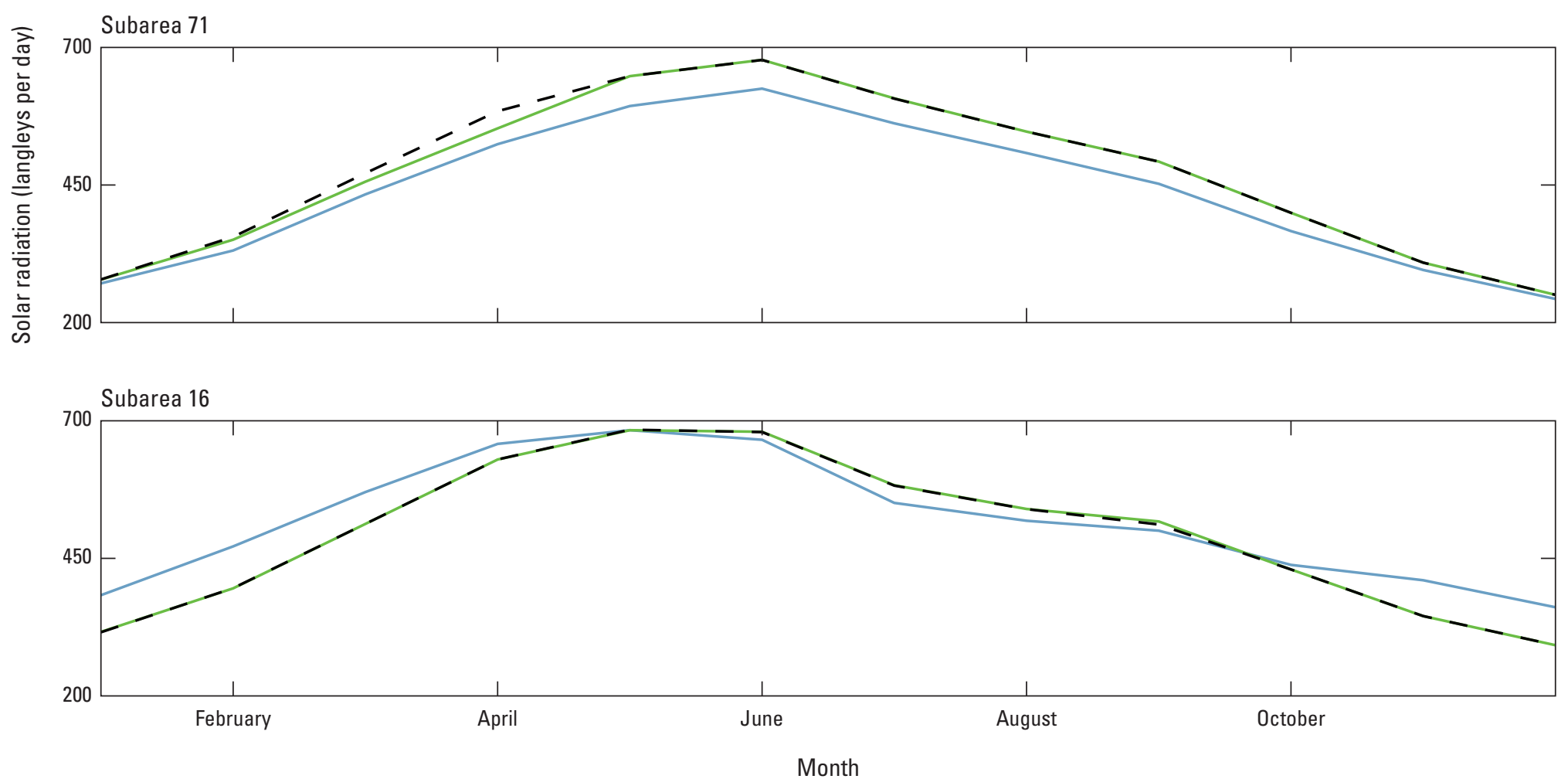

Figure 5. A, Solar radiation and $B$, potential evapotranspiration model simulations for the National Hydrologic Model (uncalibrated) initial parameters, calibrated parameters, and observed values at the mean monthly time-step for selected subareas in the upper (subarea 124), middle (subarea 71), and lower (subarea 16) parts of the Upper Rio Grande Basin; $C$, Solar radiation and $D$, potential evapotranspiration for National Hydrologic Model (uncalibrated) initial parameters, calibrated parameters, and observed values at the mean monthly time-step for the nine near-native subbasins. 


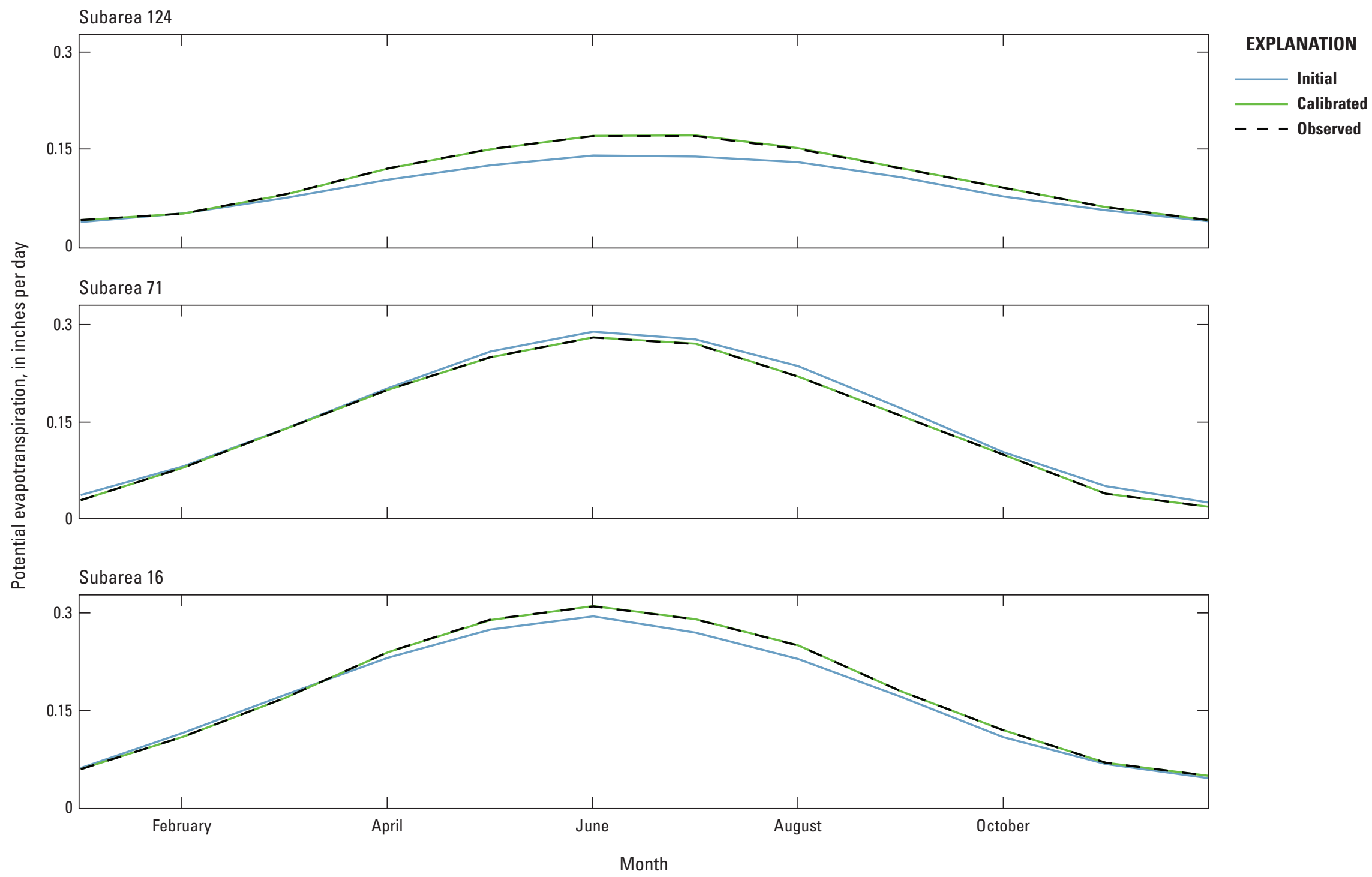

Figure 5. $A$, Solar radiation and $B$, potential evapotranspiration model simulations for the National Hydrologic Model (uncalibrated) initial parameters, calibrated parameters, and observed values at the mean monthly time-step for selected subareas in the upper (subarea 124), middle (subarea 71), and lower (subarea 16) parts of the Upper Rio Grande Basin; $C$, Solar radiation and $D$, potential evapotranspiration for National Hydrologic Model (uncalibrated) initial parameters, calibrated parameters, and observed values at the mean monthly time-step for the nine near-native subbasins.-Continued 

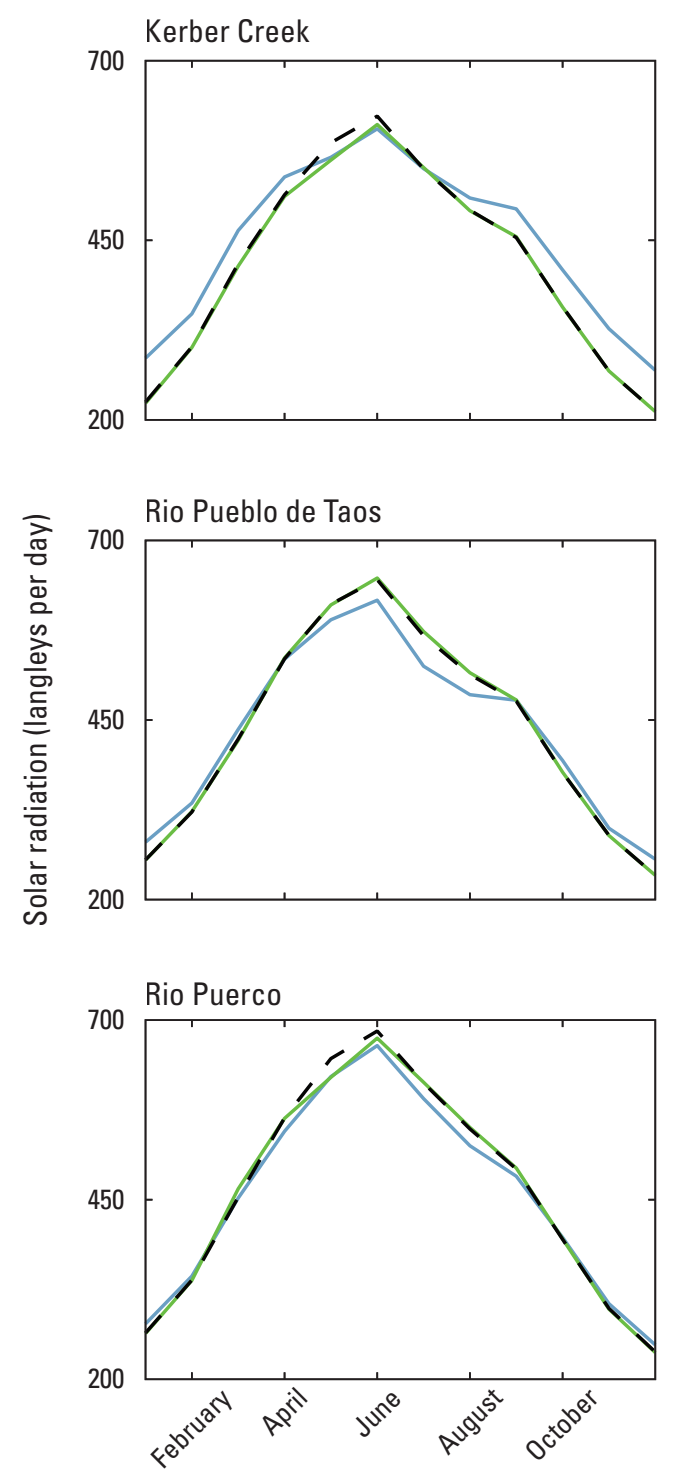

\section{Pinos Creek}

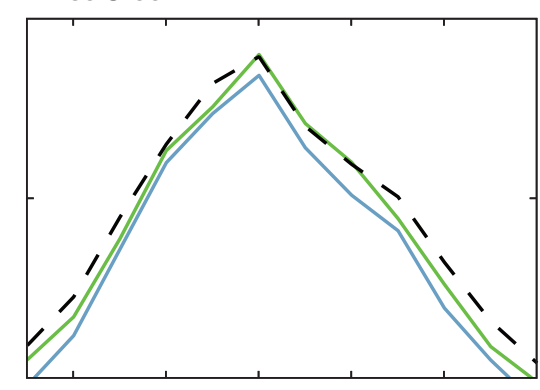

Rio Grande del Rancho

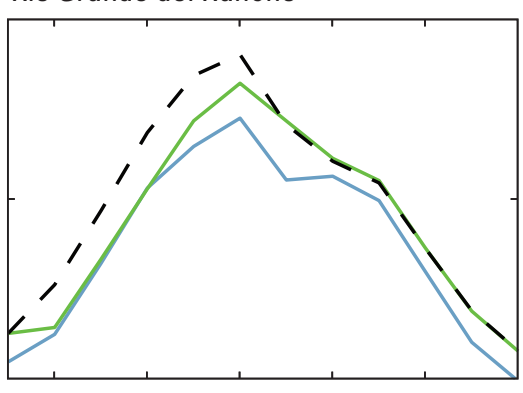

Arroyo Chico

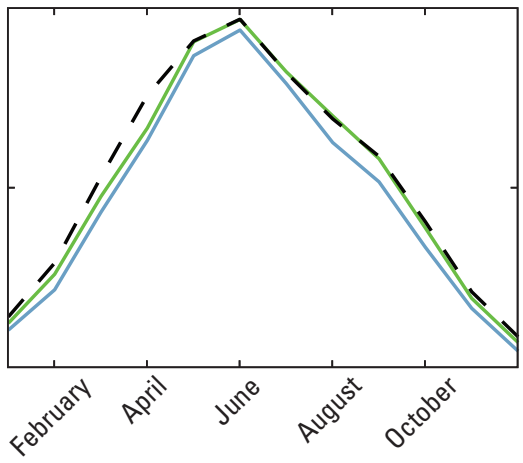

Alamosa River

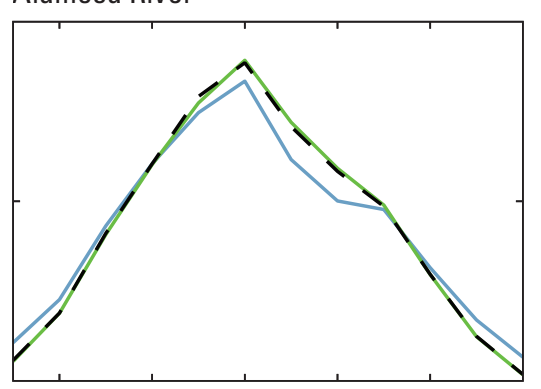

Jemez River

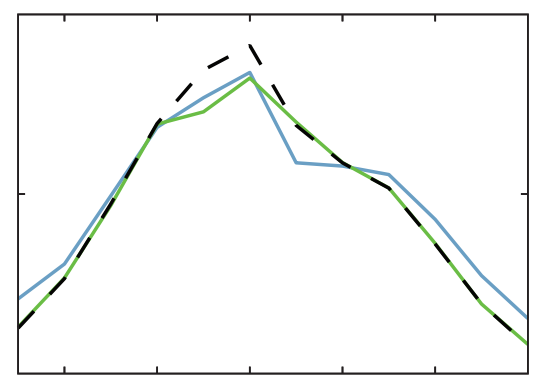

Rio Salado

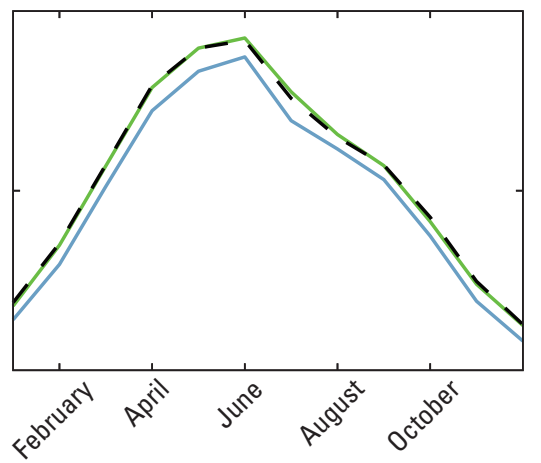

\section{EXPLANATION}

Initial

Calibrated

Figure 5. A, Solar radiation and $B$, potential evapotranspiration model simulations for the National Hydrologic Model (uncalibrated) initial parameters, calibrated parameters, and observed values at the mean monthly time-step for selected subareas in the upper (subarea 124), middle (subarea 71), and lower (subarea 16) parts of the Upper Rio Grande Basin; $C$, Solar radiation and $D$, potential evapotranspiration for National Hydrologic Model (uncalibrated) initial parameters, calibrated parameters, and observed values at the mean monthly time-step for the nine near-native subbasins.-Continued 

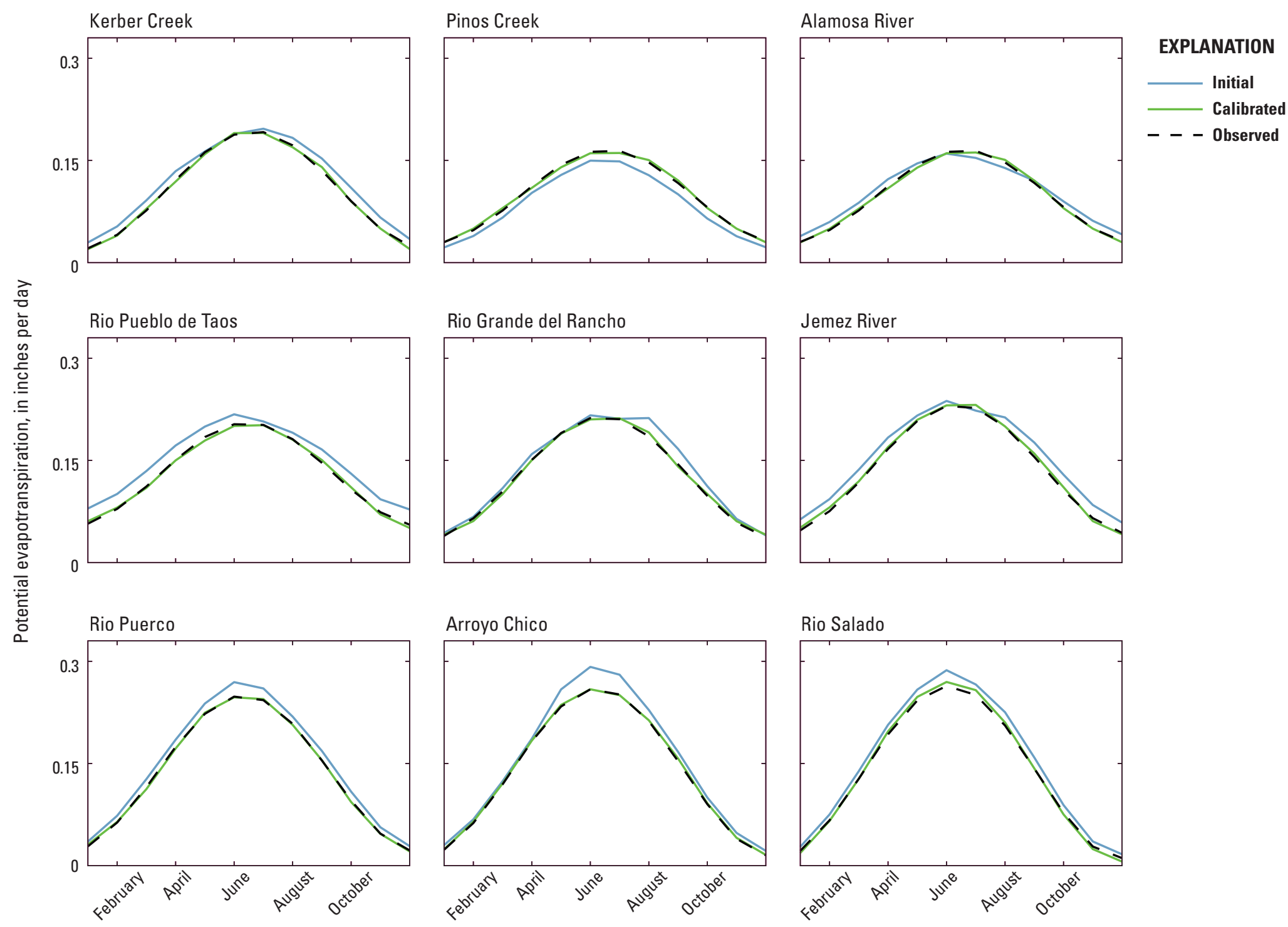

Month

Figure 5. A, Solar radiation and $B$, potential evapotranspiration model simulations for the National Hydrologic Model (uncalibrated) initial parameters, calibrated parameters, and observed values at the mean monthly time-step for selected subareas in the upper (subarea 124), middle (subarea 71), and lower (subarea 16) parts of the Upper Rio Grande Basin; C, Solar radiation and D, potential evapotranspiration for National Hydrologic Model (uncalibrated) initial parameters, calibrated parameters, and observed values at the mean monthly time-step for the nine near-native subbasins. - Continued 

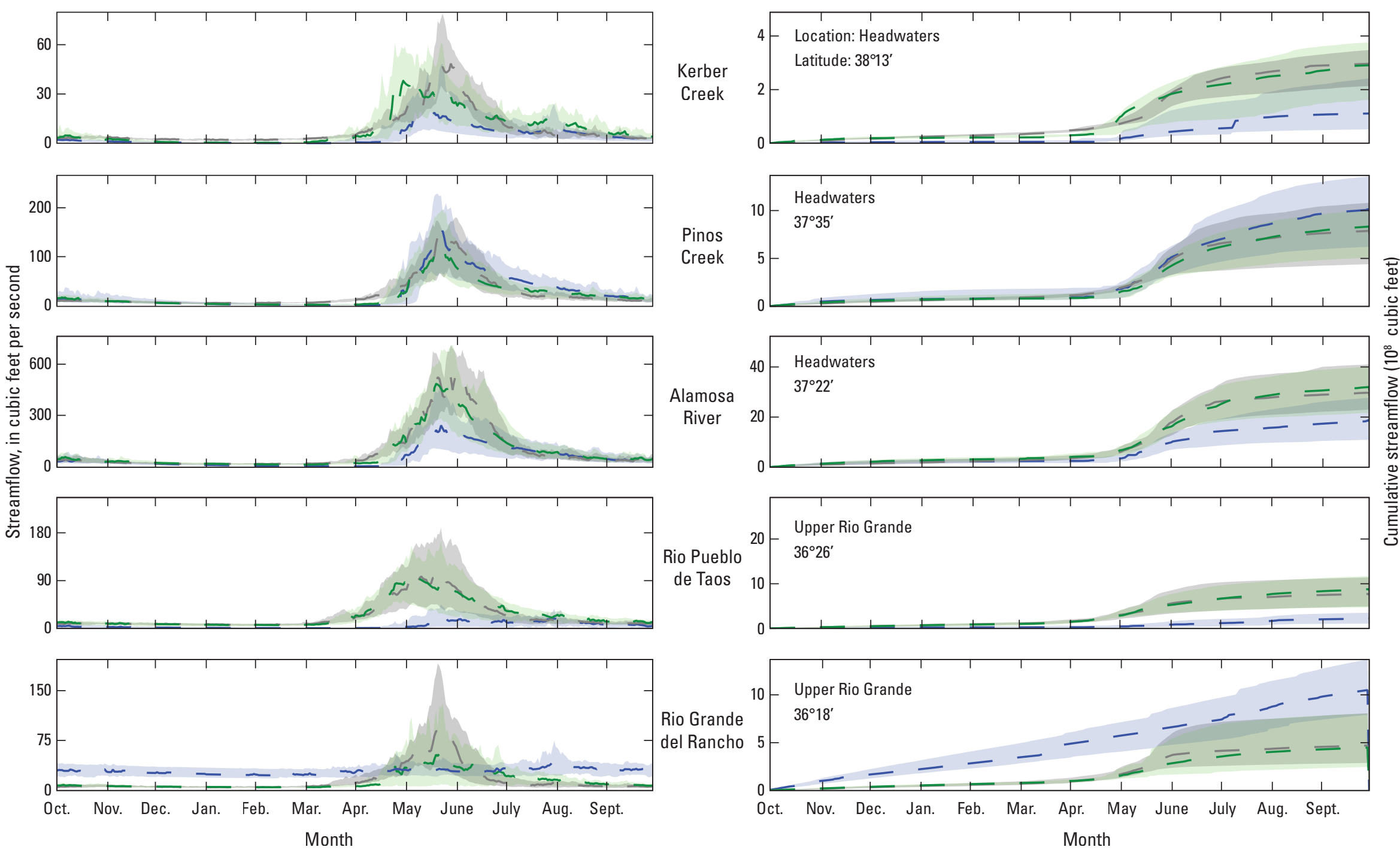

\section{EXPLANATION}

25-75\% quantile range ', ' Median NHM Calibrated model (simulated natural streamflow) Streamgage (observed streamflow)

Figure 6. Hydrographs and cumulative mean daily streamflow model simulations for the National Hydrologic Model (uncalibrated) initial parameters, calibrated parameters, and observed values for the period 1980-2015. 

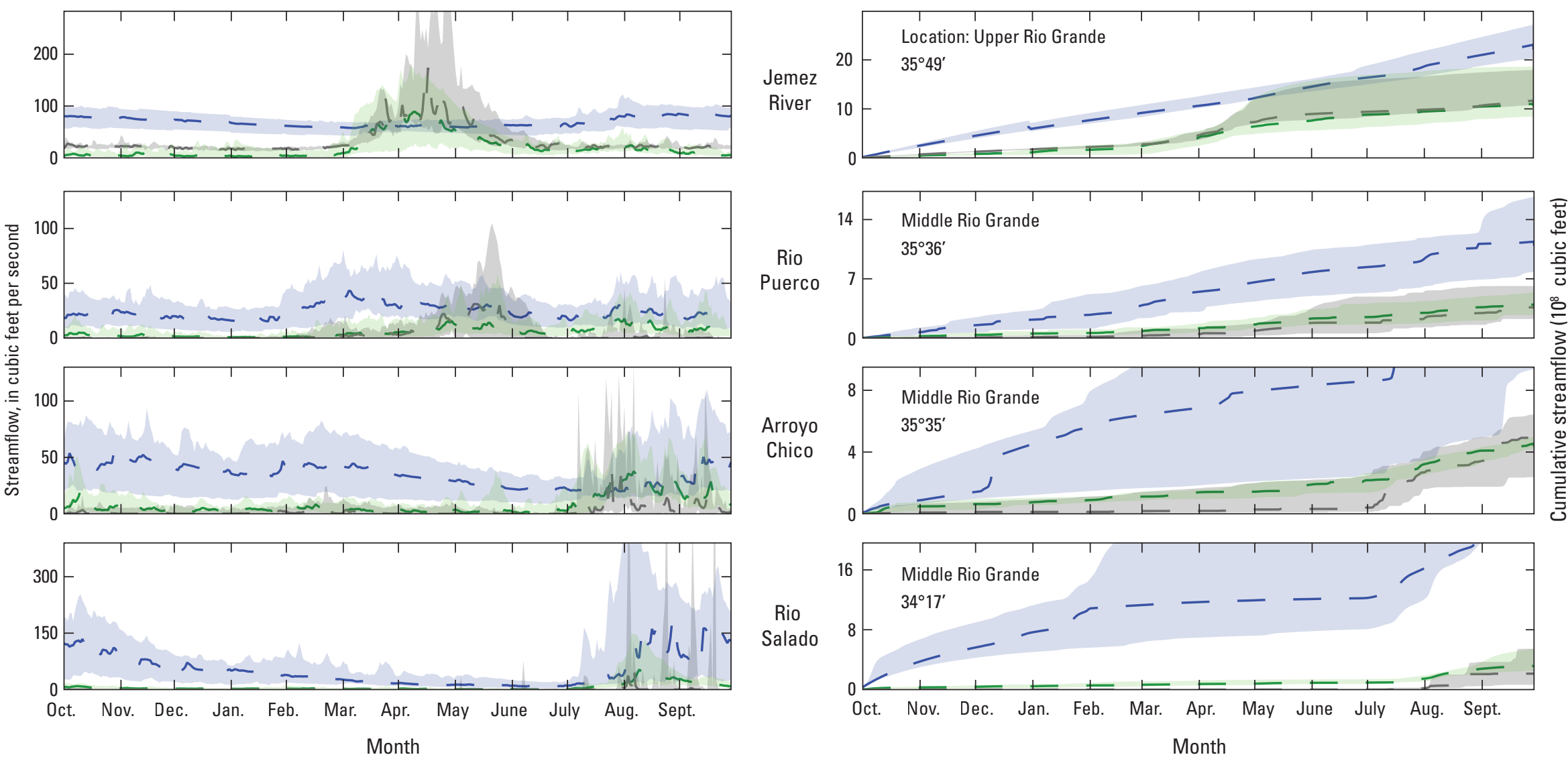

\section{EXPLANATION}

25-75\% quantile range ,' Median Calibrated model (simulated natural streamflow)

Figure 6. Hydrographs and cumulative mean daily streamflow model simulations for the National Hydrologic Model (uncalibrated) initial parameters, calibrated parameters and observed values for the period 1980-2015. Hydrographs and cumulative mean daily streamflow model simulations for the National Hydrologic Model (uncalibrated) initial parameters, calibrated parameters, and observed values for the period 1980-2015.-Continued 


\section{Model Application To Simulate Near-Native Streamflows}

The calibrated URGB-PRMS model was used to simulate streamflow at several existing streamgage locations on the mainstem of the Rio Grande in the Upper Rio Grande Basin (table 10, fig. 2). As expected, simulated mean annual nearnative streamflow in this study was greater than observed streamflow for the period 1980-2015 at all Rio Grande streamgages, ranging from slightly greater in the north (del Norte: $897 \mathrm{ft} 3 / \mathrm{s}$ versus $863 \mathrm{ft} 3 / \mathrm{s}$ ) to much greater in the south (Fort Quitman: 4,548 ft $3 / \mathrm{s}$ versus $254 \mathrm{ft} 3 / \mathrm{s}$ ). Trends for the period were evaluated using the nonparametric Mann-Kendall trend test and Theil estimate of trend slope (Helsel and Hirsch, 2002). Mean annual streamflow generally decreased over the study period for both near-native and observed conditions at all sites as indicated by the Theil slope, with trends being significant at the central three streamgages and the magnitudes of those trends increasing from north to south to San Marcial (table 10).

Records of streamflow in the Upper Rio Grande Basin before establishment of the existing diversions and impoundments are sparse, but results from other published studies generally were similar to near-native streamflow simulated using PRMS in this study. In comparison with other estimates of near-native streamflow at San Marcial, simulated mean annual streamflow of $4,050 \mathrm{ft} 3 / \mathrm{s}$ in this study was 60 percent greater than simulated mean annual natural flows of 2,507 $\mathrm{ft}^{3} / \mathrm{s}$ (1900-2010) from Blythe and Schmidt (2018). At Fort Quitman, simulated annual mean near-native streamflow in this study ranged from 1,455 to $7,821 \mathrm{ft} 3 / \mathrm{s}$. The minimum annual mean streamflow compares favorably with other estimates of minimum natural flows of 1,230 ft3/s (Enríquez Coyro, 1976) and $1,570 \mathrm{ft} 3 / \mathrm{s}$ (Blythe and Schmidt, 2018) but the maximum annual mean simulated streamflow exceeds prior estimates of maximum natural flows of $3,471 \mathrm{ft} 3 / \mathrm{s}$
(Enríquez Coyro, 1976) and 4,143 ft³/s (Blythe and Schmidt, 2018). This general overestimation might be due, in part, to (a) the general dearth of calibration sites in the southern part of the basin combined with overestimation bias in the three most southerly sites (table 5) used to distribute parameters to that part of the basin; (b) the tendency of the near-native subbasins used for parameter distribution to be situated in higher elevation, higher rainfall parts of the basin, which might not have been fully offset by the variable-dependency algorithms during parameter distribution; (c) the limitations of PRMS to simulate groundwater-surface water interactions; or (d) biases in Daymet climate data.

Nonetheless, biases observed during calibration and validation of the model (table 5) provide overall support for its performance. Results of this study indicate that the anthropogenic effects of water impoundment, diversion, and consumption have reduced streamflow from that under near-native conditions. Importantly, our process-based modeling approach indicates that near-native conditions result in greater streamflow than previously estimated, particularly in wet years, perhaps because of a better representation of nonlinear rainfallrunoff processes for high runoff-rate events and wet years.

Simulated near-native streamflow was compared to observed streamflow to provide an estimate of the effects of anthropogenic influences at five streamgage sites along the mainstem Rio Grande (fig. 2). The most northerly streamgage (Rio Grande near del Norte, Colo. 08220000) had observed annual flows both greater and less than near-native annual flows over the 36-year (1980-2015) period (fig. 7), with a median change of -4 percent (observed flow less than near-native flows). Flows at the other streamgage sites were substantially less for observed conditions than near-native conditions, with median changes of -84 percent for Rio Grande at the Colorado-New Mexico State Line (08252000), -57 percent for Rio Grande at Otowi Bridge, N. Mex. (08313000),

Table 10. Mean annual streamflow (1980-2015) and trends (S) for Precipitation-Runoff Modeling System (PRMS)-simulated near-native streamflow and observed streamgage data in the Upper Rio Grande Basin.

[USGS, U.S. Geological Survey; S, Theil slope; $\mathrm{ft} 3 / \mathrm{s}$, cubic foot per second; $\mathrm{ft} 3 \mathrm{~s} / \mathrm{yr}$, cubic foot per second per year; CODWR, Colorado Division of Water Resources; CO, Colorado; NM, New Mexico; TX, Texas]

\begin{tabular}{|c|c|c|c|c|}
\hline \multirow[b]{2}{*}{ USGS streamgage } & \multicolumn{2}{|c|}{ PRMS } & \multicolumn{2}{|c|}{ Observed } \\
\hline & $\begin{array}{l}\text { Mean } \\
(\mathrm{ft} t \mathbf{s})\end{array}$ & $\begin{array}{c}\text { S } \\
(\mathbf{f t} 3 / \mathbf{s} / \mathbf{y r})\end{array}$ & $\begin{array}{l}\text { Mean } \\
(\mathbf{f t} 3 / \mathbf{s})\end{array}$ & $\begin{array}{c}\mathbf{S} \\
\left(\mathrm{ft} \mathbf{t}^{3} / \mathrm{s} / \mathrm{yr}\right)\end{array}$ \\
\hline 0628222 Pinos Creek near del Norte, CO${ }^{1}$ & 897 & -7.1 & 863 & -6.7 \\
\hline 08252000 Rio Grande at Colorado-New Mexico State line & 2,386 & $-21.2 *$ & 447 & $-9.3^{* *}$ \\
\hline 08313000 Rio Grande at Otowi bridge, NM & 3,324 & $-37.2 *$ & 1,444 & $-28.9 * *$ \\
\hline 08358400 Rio Grande floodway at San Marcial, NM & 4,050 & $-42.1^{*}$ & 840 & $-28.2^{* *}$ \\
\hline 08370500 Rio Grande at Fort Quitman, TX & 4,548 & -20.2 & 254 & $-4.1^{*}$ \\
\hline
\end{tabular}

Mann-Kendall test significance: ${ }^{*} \mathrm{p}<0.10,{ }^{* *} \mathrm{p}<0.05$.

${ }^{1}$ Former USGS streamgage 08220500, now CODWR streamgage 062822. 


\section{Application of PRMS To Simulate Near-Native Streamflow, Upper Rio Grande Basin}

-82 percent for Rio Grande Floodway at San Marcial, N. Mex. (08358400), and -95 percent for Rio Grande at Fort Quitman, Tex. (08370500).

Hydrographs of simulated and observed mean daily streamflow show the effect of anthropogenic influence on the magnitude of flows and the diminishment of peak flows along the mainstem Rio Grande as it exits the San Juan Mountains, enters the San Luis Valley, and flows south to Texas (fig. 8). Observed streamflow entering the San Luis Valley at the Rio Grande near del Norte streamgage (08220000) is similar to natural flows produced by the PRMS model, with differences in flow attributed to small dams and diversions upstream. As the river flows southward past the streamgage at the Colorado-New Mexico State line (08252000), the magnitude of observed streamflow is substantially lower than simulated natural streamflow and a distinct snowmelt runoff peak is almost nonexistent. Compact regulation, agricultural diversions, and groundwater pumping in and around the San Luis Valley affect flows at the streamgage.
At the Otowi Bridge (08313000) streamgage in northern New Mexico, the difference between simulated natural flow and observed streamflow decreases with tributary inflow, but peak flows have been greatly affected by diversions and regulation at multiple upstream reservoirs. In the southern part of the basin, at the Rio Grande near San Marcial (08358400) north of Elephant Butte Reservoir, the peak flow signal in observed streamflow is further diminished and the magnitude of flow is greatly reduced. Flow upstream from the streamgage at San Marcial is affected by groundwater pumping, dams, agricultural diversions, and by municipal water use by the City of Albuquerque and smaller cities upstream. By the time streamflow reaches the streamgage at Fort Quitman, Tex. (08370500), it is nearly depleted. The hydrograph of observed mean daily streamflow shows the dramatic integrated effects of groundwater pumping, reservoir regulation, agricultural and municipal water use upstream, and other anthropogenic and natural factors (such as drought) on the flow of the Rio Grande. 


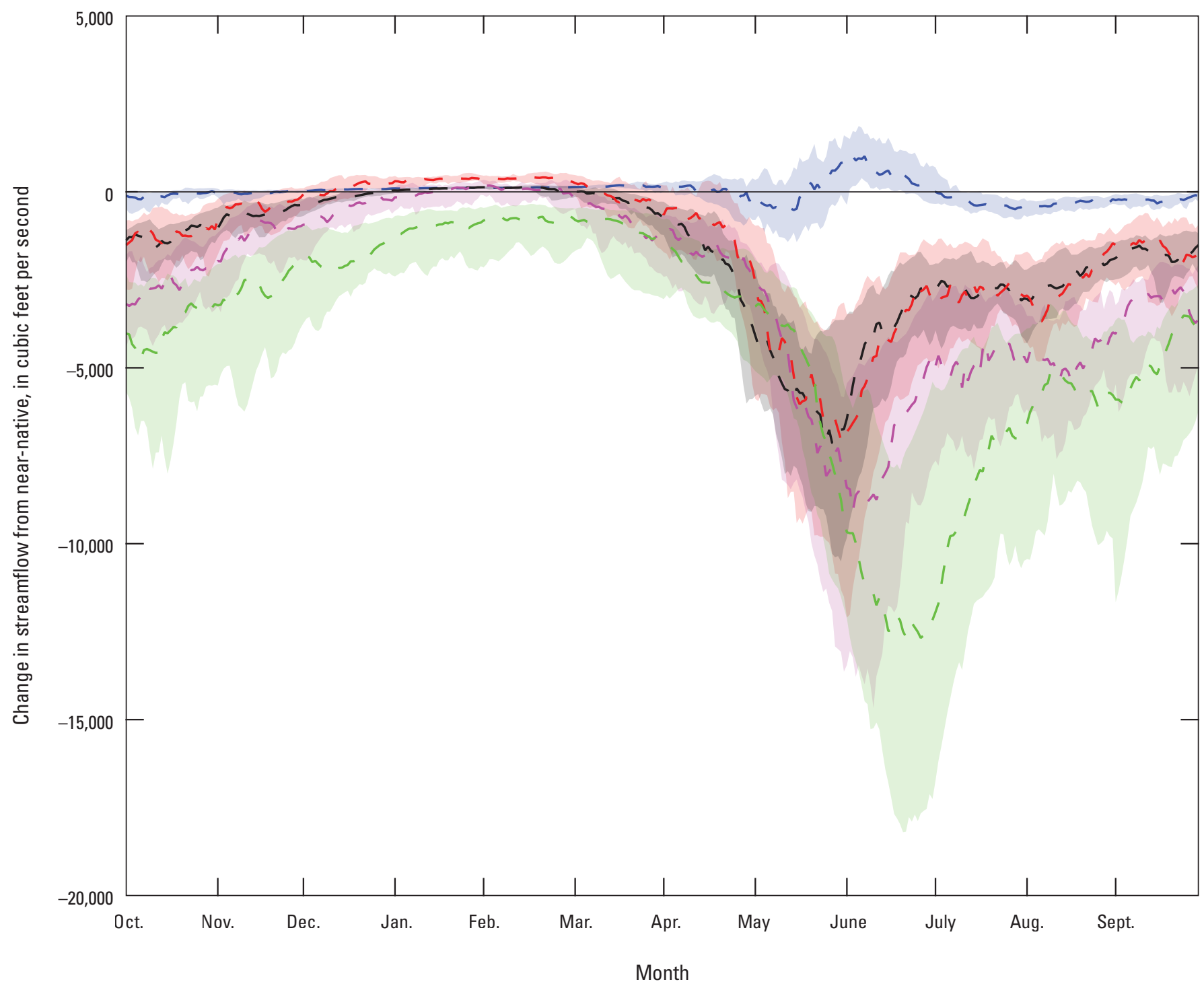

\section{EXPLANATION}

\section{Del Norte}

State line

Otowi

San Marcial

Fort Quitman

25-75\% quantile range

, ' Median

Figure 7. Change in mean daily streamflow from simulated near-native to observed flows in the Upper Rio Grande Basin during the period 1980-2015. U.S. Geological Survey streamgages along the mainstem Rio Grande (from north to south): Rio Grande near del Norte, Colo. (08220000); Rio Grande at Colorado-New Mexico State Line (08252000); Rio Grande at Otowi Bridge, N. Mex. (08313000); Rio Grande Floodway at San Marcial, N. Mex. (08358400); Rio Grande at Fort Quitman, Tex. (08370500). 

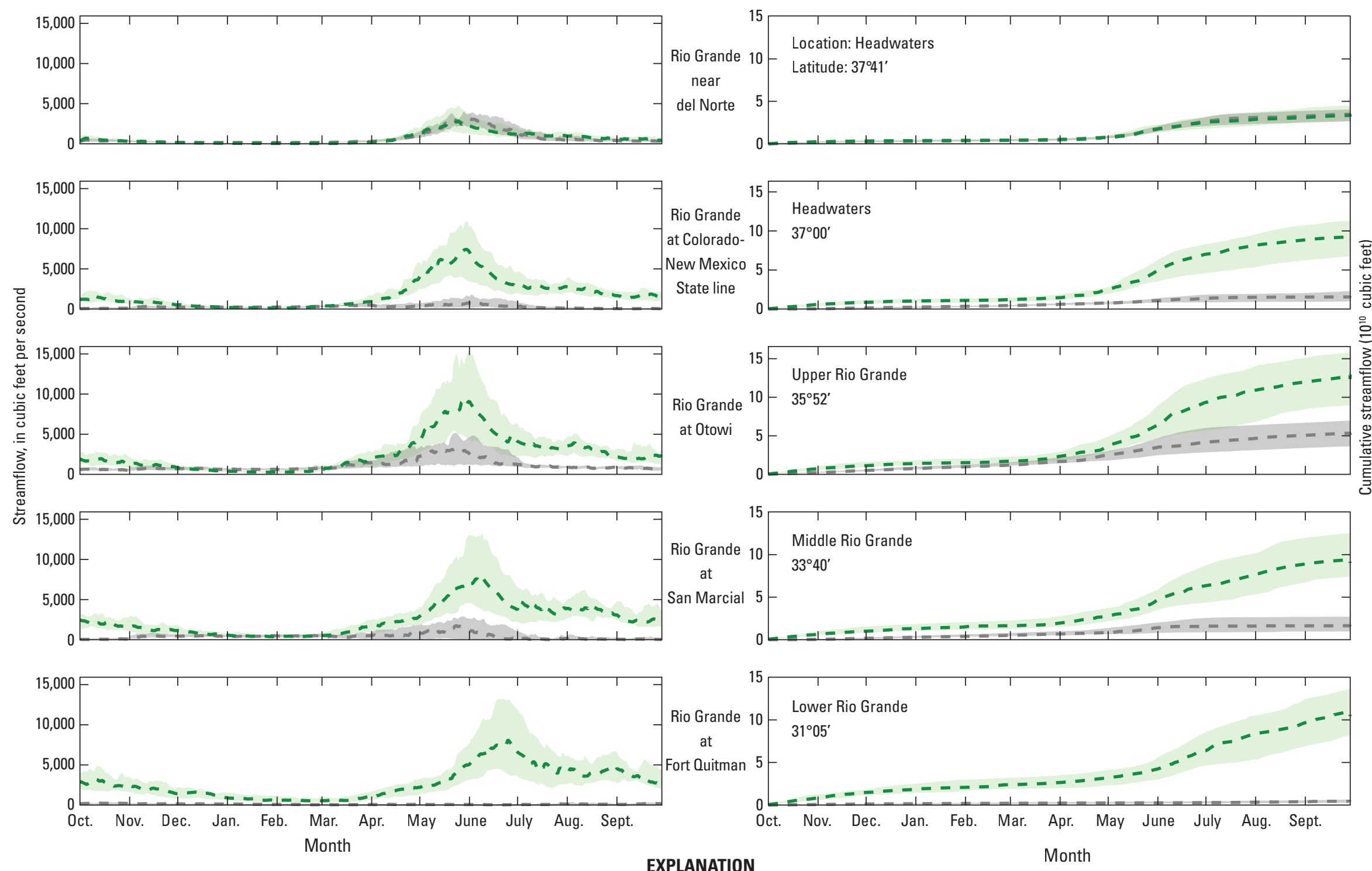

25-75\% quantile range , 、 Median NHM Calibrated model (simulated natural streamflow)

Figure 8. Hydrograph of model simulated (postcalibration) natural flow and observed mean daily streamflow, and cumulative daily model simulated (postcalibration) natural flow and observed streamflow for sites on the mainstem Rio Grande for the period 1980-2015. 


\section{Summary and Conclusions}

The Precipitation-Runoff Modeling System (PRMS) is widely used to simulate the effects of climate, topography, land cover, and soils on landscape-level hydrologic responses and streamflow. A PRMS model of the Upper Rio Grande Basin that simulates near-native streamflow conditions was developed, calibrated, and assessed for this study. The PRMS model was adapted from the National Hydrologic Model (NHM) infrastructure and calibrated through multiple steps. First, solar radiation and potential evapotranspiration were calibrated by subarea for all hydrologic response units in the model domain. Then nine "near-native" subbasins were identified and streamflow parameters were calibrated in each of these subbasins. The calibrated streamflow parameters were distributed to the remaining noncalibrated hydrologic response units on the basis of terrain, soil, and vegetation conditions linked to a distribution and weighting algorithm developed for this study. The parameter distribution method was validated for three of the nine near-native subbasins and compared to both observed streamflow and simulated streamflow using initial and calibrated parameters.

In general, calibration results showed improvements over using initial NHM parameters and demonstrate the value of model calibration at the local level. Results for the calibration of solar radiation and potential evapotranspiration for selected subareas and near-native subbasins improved slightly in comparison to initial NHM parameters, but generally simulations with initial parameters were good prior to calibration. Results for the calibration of streamflow were satisfactory (Nash-Sutcliffe efficiency [NSE] $>0.5$, bias $< \pm 10$ percent) or better for all near-native subbasins except Rio Salado (bias = about 31 percent), the southernmost subbasin with the shortest period of record for observed streamflow. The model performed better for the northern snowmelt-dominated subbasins than for the monsoon-dominated subbasins in the central and southern parts of the basin. The same held true for the distribution of calibrated streamflow parameters to the rest of the model domain. In validating the distribution method, model performance of simulated streamflow using newly generated parameters for three of the nine near-native subbasins was good to satisfactory for the two northerly located subbasins, Pinos Creek and Rio Pueblo de Taos (NSE > 0.50 and bias 2.4 to 16.6 percent), indicating that simulations of naturalized flow for the northern hydrologic response units, where more than 75 percent of Rio Grande streamflow is generated, should be satisfactory. Results for the centrally located Rio Puerco subbasin were found to have unsatisfactory NSE (0.09) but had a good underestimation bias ( -10.1 percent). Calibrated model performance throughout the entire Upper Rio Grande Basin is vastly improved in comparison to initial NHM parameters, demonstrating that the new model is appropriate for simulating near-native conditions throughout the basin.

The calibrated PRMS model was used to simulate flows at five existing streamgage locations on the mainstem of the Rio Grande. Results of those simulations help to quantify the effect that anthropogenic influences, such as regulation at dams and diversions of water for agricultural or municipal use, has had on Rio Grande streamflow. Simulated near-native streamflow and observed flow exiting the San Juan Mountains in the headwaters region of the basin at the Rio Grande near del Norte, Colo., streamgage are nearly identical, with observed flow being about 4 percent (median change) less than simulated flow over the period of simulation (1980-2015). As the river flows southward, the compounding effects of both natural and anthropogenic influence on streamflow are evident. At Fort Quitman, Tex., median observed flow is 95 percent less than simulated near-native flow for the period of simulation.

Results presented in this study are similar to estimates of naturalized flow from other studies in the basin at low flows, but at high flows, magnitudes of annual mean streamflow estimated in this study are higher than estimates in other studies. However, each of these studies use different methods with different limitations and each looks at different time periods. For example, the use of rigorous methods for identifying and selecting near-native river basins in this study resulted in the use of only nine basins for calibration and distribution of streamflow parameters. All but three of the selected near-native subbasins were in the mid-upper part of the Upper Rio Grande Basin and situated at high elevations. Two of the near-native subbasins in the southern part of the basin used to distribute parameters to the Lower Rio Grande section of the basin had limited calibration streamflow data (Arroyo Chico and Rio Salado), and postcalibration simulations are biased toward higher values in comparison to observed values. Therefore, a combination of both model bias in streamflow estimation and the ephemeral nature of streamflow in the southern part of the basin contribute to higher estimations of streamflow along mainstem Rio Grande sites in the lower portion of the basin (south of Albuquerque, N. Mex.).

Streamflow regulation, water use, and multiple years of drought have all affected streamflow in the Upper Rio Grande Basin. Increasing demand on limited freshwater resources in the basin and the effect that changes in future climate may have on water resources will put pressure on resource management agencies to balance the competing needs of ecosystem health with municipal, agricultural, and other uses. The new PRMS model for the Upper Rio Grande Basin developed in this study is a tool that can simulate naturalized streamflow and associated hydrologic variables at the daily time step and can be used in conjunction with other models to aid in current and future management of water resources in the basin.

\section{Acknowledgments}

The authors wish to thank the following USGS employees for providing insight in developing and calibrating the Upper Rio Grande Basin PRMS model: Jacob LaFontaine, Steve Regan, and Lauren Hay. This research was partially funded by the Department of the Interior South Central Climate Adaptation Science Center. 


\section{References Cited}

Archfield, S.A., Kennen, J.G., Carlisle, D.M., and Wolock, D.M., 2014, An objective and parsimonious approach for classifying nature flow regimes at a continental scale: River Research and Applications, v. 30, no. 9, p. 1166-1183. [Also available at https://doi.org/10.1002/rra.2710].

Beven, K.J., 2002, Towards a coherent philosophy for environmental modeling: Proceedings of the Royal Society of London. Series A: Mathematical, Physical and Engineering Sciences, v. 458, no. 2026, p. 2465-2484. [Also available at https://doi.org/10.1098/rspa.2002.0986].

Blodgett, D.L., Booth, N.L., Kunicki, T.C., Walker, J.I., and Viger, R.J., 2011, Description and testing of the Geo Data Portal-A data integration framework and Web processing services for environmental science collaboration: U.S. Geological Survey Open-File Report 2011-1157, 9 p., accessed March 2019 at https://doi.org/10.3133/ ofr20111157.

Blythe, T.L., and Schmidt, J.C., 2018, Estimating the natural flow regime of rivers with long-standing developmentThe Northern branch of the Rio Grande: Water Resources Research, v. 54, no. 2, p. 1212-1236. [Also available at https://doi.org/10.1002/2017WR021919].

Carlisle, D.M., Falcone, J., Wolock, D.M., Meador, M.R., and Norris, R.H., 2010, Predicting the natural flow regimeModels for assessing hydrological alteration in streams: River Research and Applications, v. 26, no. 2, p. 118-136. [Also available at https://doi.org/10.1002/rra.1247].

Chavarria, S.B., Moeser, C.D., and Shephard, Z., 2020, Input and output data for the application of the PrecipitationRunoff Modeling System (PRMS) to simulate near-native streamflow in the Upper Rio Grande Basin: U.S. Geological Survey data release, https://doi.org/10.5066/P9YOPYW7.

Colorado Division of Water Resources [CODWR], 2017, Colorado's Surface Water Conditions: Colorado Division of Water Resources database, accessed November 2019 at https://dwr.state.co.us/Surfacewater/default.aspx.

DiNatale Water Consultants, 2014, Rio Grande Basin Water Plan, 388 p., accessed January 2019 at https://www.colorado.gov/pacific/sites/default/files/ 14WaterResourcesBasinImplementationPlanRioGrande Basin.pdf.

Douglas-Mankin, K.R., and Moeser, C.D., 2019, Calibration of Precipitation-Runoff Modeling System (PRMS) to simulate prefire and postfire hydrologic response in the upper Rio Hondo Basin, New Mexico: U.S. Geological Survey Scientific Investigations Report 2019-5022, 25 p., accessed August 2019 at https://doi.org/10.3133/sir20195022.
Driscoll, J.M., Markstrom, S.L., Regan, R.S., Hay, L.E., and Viger, R.J., 2017, National Hydrologic Model Parameter Database: 2017-05-08 Download: U.S. Geological Survey, accessed March 2017 at https://doi.org/10.5066/ F7NSOSCW.

Enríquez Coyro, E., 1976, El tratado entre México y los Estados Unidos de América sobre ríos internacionales. Facultad de Ciencias Políticas y Sociales: Mexico City, Mexico, Universidad Nacional Autónoma de México.

Falcone, J.A., Carlisle, D.M., Wolock, D.M., and Meador, M.R., 2010, GAGES-A stream gage database for evaluating natural and altered flow conditions in the coterminous United States: Ecology, v. 91, no. 2, p. 621. [Also available at https://doi.org/10.1890/09-0889.1].

Farnsworth, R.K., Thompson, E.S., and Peck, E.L., 1982, Evaporation atlas for the contiguous 48 United StatesNOAA Technical Report NWS 33: Washington, D.C., U.S. Department of Commerce, 26 p.

Ficklin, D.L., Abatzoglou, J.T., Robeson, S.M., Null, S.E., and Knouft, J.H., 2018, Natural and managed watersheds show similar responses to recent climate change: Proceedings of the National Academy of Sciences of the United States of America, v. 115, no. 34, p. 8553-8557. [Also available at https://doi.org/10.1073/pnas.1801026115].

Glaser, L.S., 1998, The San Juan-Chama Project, Bureau of Reclamation History Program, 28 p., accessed November 2019 at https://www.usbr.gov/projects/ pdf.php?id=186.

Gleeson, T., Smith, L., Moosdorf, N., Hartmann, J., Dürr, H.H., Manning, A.H., van Beek, L.P.H., and Jellinek, A.M., 2011, Mapping permeability over the surface of the Earth: Geophysical Research Letters, v. 38, no. 2, p. 1-6. [Also available at https://doi.org/10.1029/2010GL045565].

Gonzalez, P., Garfin, G.M., Breshears, D.D., Brooks, K.M., Brown, H.E., Elias, E.H., Gunasekara, A., Huntly, N., Maldonado, J.K., Mantua, N.J., Margolis, H.G., McAfee, S., Middleton, B.R., and Udall, B.H., 2018, Chapter 25 Southwest, In Impacts, Risks, and Adaptation in the United States: Fourth National Climate Assessment, Volume II [Reidmiller, D.R., Avery, C.W., Easterling, D.R., Kunkel, K.E., Lewis, K.L.M., Maycock, T.K., and Stewart, B.C. (eds.)], U.S. Global Change Research Program, Washington, DC, USA, pp. 1101-1184, accessed September 2019 at https://nca2018.globalchange.gov/chapter/25/.

Harmel, R.D., Baffaut, C., and Douglas-Mankin, K.R., 2018, Review and development of ASABE Engineering Practice 621-Guidelines for calibrating, validating, and evaluating hydrologic and water quality models: Transactions of the ASABE, v. 61, no. 4, p. 1393-1401. [Also available at https://doi.org/10.13031/trans.12806]. 
Hay, L.E., 2019, Application of the National Hydrologic Model Infrastructure with the Precipitation-Runoff Modeling System (NHM-PRMS), by HRU Calibrated Version: U.S. Geological Survey data release, accessed April 2019 at https://doi.org/10.5066/P9NM8K8W.

Hay, L.E., and Umemoto, M., 2006, Multiple-objective stepwise calibration using LUCA: U.S. Geological Survey Open-File Report 2006-1323, 25 p. [Also available at https://doi.org/10.3133/ofr20061323].

Hay, L.E., Leavesley, G.H., Clark, M.P., Markstrom, S.L., Viger, R.J., and Umemoto, M., 2006, Step wise, multiple objective calibration of a hydrologic model for a snowmelt dominated basin: Journal of the American Water Resources Association, v. 42, no. 4, p. 877-890. [Also available at https://doi.org/10.1111/j.1752-1688.2006.tb04501.x].

Helsel, D.R., and Hirsch, R.M., 2002, Statistical methods in water resources techniques of water resources investigations of the U.S. Geological Survey, book 4, chap. A3., 522 p., [Also available at https://water.usgs.gov/pubs/twri/ twri4a3/].

Homer, C., Dewitz, J., Fry, J., Coan, M., Hossain, N., Larson, C., Herold, N., McKerrow, A., VanDriel, J.N., and Wickham, J., 2007, Completion of the 2001 National Land Cover Database for the conterminous United States: Photogrammetric Engineering and Remote Sensing, v. 73, no. 4, p. 337-341.

International Boundary and Water Commission [IBWC], 2019, Rio Grande Historical Mean Daily Discharge Data: International Boundary and Water Commission database, accessed November 2019 at https://www.ibwc.gov/Water_ Data/histflo1.htm.

Kirchner, J.W., 2006, Getting the right answers for the right reasons-Linking measurements, analyses, and models to advance the science of hydrology: Water Resources Research, v. 42, no. 3, p. 1-5. [Also available at https://doi.org/10.1029/2005WR004362].

Leavesley, G.H., Lichty, R.W., Troutman, B.M., and Saindon, L.G., 1983, Precipitation Runoff Modeling SystemUser's manual: U.S. Geological Survey Water-Resources Investigations Report 83-4238, 207 p.

Llewellyn, D., and Vaddey, S., 2013, West-wide climate risk assessment-Upper Rio Grande impact assessment-U.S. Bureau Reclamation: Albuquerque, N. Mex., Upper Colorado Region, 138 p.

Markstrom, S.L., Hay, L.E., and Clark, M.P., 2016, Towards simplification of hydrologic modeling-Identification of dominant processes: Hydrology and Earth System Sciences, v. 20: p. 4655-4671. [Also available at https://doi.org/ 10.5194/hess-20-4655-2016].
Markstrom, S.L., Regan, R.S., Hay, L.E., Viger, R.J., Webb, R.M.T., Payn, R.A., and LaFontaine, J.H., 2015, PRMSIV, the Precipitation-Runoff Modeling System, version 4: U.S. Geological Survey Techniques and Methods, Book 6, Chap. B7, 158 p. [Also available at https://doi.org/10.3133/ tm6B7].

Miller, M.P., Carlisle, D.M., Wolock, D.M., and Wieczorek, M., 2018a, A database of natural monthly streamflow estimates from 1950 to 2015 for the conterminous United States: Journal of the American Water Resources Association, v. 54, no. 6 p. 1258-1269. [Also available at https://doi.org/10.1111/1752-1688.12685 ].

Miller, M.P., Carlisle, D.M., Wolock, D.M., and Wieczorek, M.E., 2018b, Natural monthly flow estimates for the conterminous United States, 1950-2015: U.S. Geological Survey data release, https://doi.org/10.5066/F7CC0ZMG.

Moriasi, D.N., Zeckoski, R.W., Arnold, J.G., Baffaut, C., Malone, R.W., Daggupati, P., Guzman, J.A., Saraswat, D., Yuan, Y., Wilson, B.N., Shirmohammadi, A., and Douglas-Mankin, K.R., 2015, Hydrologic and water quality models-Key calibration and validation topics: Transactions of the ASABE, v. 58, no. 6, p. 1609-1618. [Also available at https://doi.org/10.13031/trans.58.11075].

Natural Resources Conservation Service [NRCS], 2013, Soil Survey Geographic (SSURGO) Database, Natural Resources Conservation Service website, accessed February 15, 2020, at https://websoilsurvey.nrcs.usda.gov/.

Natural Resources Conservation Service [NRCS], 2019, Forecasting: Water supply and water management in the West, accessed July 2019 at https://www.wcc.nrcs.usda.gov/ about/forecasting.html.

New Mexico Office of the State Engineer/Interstate Stream Commission [NMOSE/ISC], 2016a, Region 3-Jemez y Sangre Regional Water Plan, 268 p., accessed September 6, 2019, at https://www.ose.state.nm.us/Planning/ region_03.php.

New Mexico Office of the State Engineer/Interstate Stream Commission [NMOSE/ISC], 2016b, Region 7-Taos Regional Water Plan, 240 p., accessed September 6, 2019, at https://www.ose.state.nm.us/Planning/region_07.php.

New Mexico Office of the State Engineer/Interstate Stream Commission [NMOSE/ISC], 2016c, Region 14-Rio Chama Regional Water Plan, 240 p., accessed September 6, 2019, at https://www.ose.state.nm.us/Planning/region_14.php.

New Mexico Office of the State Engineer/Interstate Stream Commission [NMOSE/ISC], 2017a, Region 12-Middle Rio Grande Regional Water Plan, 289 p., accessed September 6, 2019, at https://www.ose.state.nm.us/Planning/ region_12.php. 
New Mexico Office of the State Engineer/Interstate Stream Commission [NMOSE/ISC], 2017b, Region 11-Lower Rio Grande Regional Water Plan, 289 p., accessed September 6, 2019, at https://www.ose.state.nm.us/Planning/ region_11.php.

Paddock, W.A., 2001, Rio Grande Compact of 1938: University of Denver Water Law Review, v. 5, no. 1, p. 1-57.

Rango, A., 2006, Snow: The real water supply for the Rio Grande Basin: New Mexico: Journal of Science, v. 44, p. 99-118. [Also available at https://jornada.nmsu.edu/biblio/ snow-real-water-supply-rio-grande-basin].

Regan, R.S., Markstrom, S.L., Hay, L.E., Viger, R.J., Norton, P.A., Driscoll, J.M., LaFontaine, J.H., 2018, Description of the National Hydrologic Model for use with the Precipitation-Runoff Modeling System (PRMS): U.S. Geological Survey Techniques and Methods, book 6, chap B9, 38 p., accessed October 2018 at https://doi.org/10.3133/ tm6B9.

Regan, R.S., Juracek, K.E., Hay, L.E., Markstrom, S.L., Viger, R.J., Driscoll, J.M., LaFontaine, J.H., and Norton, P.A., 2019, The U.S. Geological Survey National Hydrologic Model infrastructure-Rationale, description, and application of a watershed-scale model for the conterminous United States: Environmental Modelling \& Software, v. 111, p. 192-203. [Also available at https://doi.org/ 10.1016/j.envsoft.2018.09.023].

State of New Mexico Water Quality Control Commission (WQCC), 2002, Water Quality and Water Pollution Control in New Mexico 2002; Part II: Surface and groundwater quality, Chapter 2 New Mexico's Surface Water Basins: Their physical descriptions, current contamination problems, and ongoing remediation efforts, p. 19-36.

Thornton, P.E., Thornton, M.M., Mayer, B.W., Wei, Y., Devarakonda, R., Vose, R.S., and Cook, R.B., 2016, Daymet-Daily surface weather data on a 1-km Grid for North America, version 3: Oak Ridge, Tenn., ORNL DAAC. [Also available at https://doi.org/10.3334/ORNLDAAC/ 1328].
U.S. Army Corps of Engineers, U.S. Geological Survey, U.S. Bureau of Reclamation, U.S. Fish and Wildlife Service, U.S. Bureau of Indian Affairs, and International Boundary and Water Commission, 2005, Upper Rio Grande water operations model, physical model documentationThird technical review committee draft, 95 p., accessed November 2019 at https://w3.spa.usace.army.mil/urgwom/ documentation/PHYMOD_Jun_2005.pdf.

U.S. Geological Survey, [USGS], 2019a, Water Availability and Use Science Program: National Water Census: U.S. Geological Survey Water Resources web page, accessed August 2019 at https://www.usgs.gov/mission-areas/ water-resources/science/water-availability-and-use-scienceprogram-national-water?qt-science_center_objects=0\#qtscience_center_objects.

U.S. Geological Survey [USGS], 2019b, USGS water data for the Nation: U.S. Geological Survey National Water Information System database, accessed November 2019 at https://doi.org/10.5066/F7P55KJN.

Viger, R.J., and Bock, A., 2014, GIS features of the Geospatial Fabric for National Hydrologic Modeling, U.S. Geological Survey, accessed October 2018 at https://doi.org/10.5066/ F7542KMD.

Viger, R.J. 2014, Preliminary spatial parameters for PRMS based on the Geospatial Fabric, NLCD2001 and SSURGO: U.S. Geological Survey, accessed October 2018 at https://doi.org/10.5066/F7WM1BF7.

Vose, R.S., Applequist, S., Squires, M., Durre, I., Menne, M.J., Williams, Claude N., Jr., Fenimore, C., Gleason, K., Arndt, D., 2014, NOAA's Gridded Climate Divisional Dataset (CLIMDIV), Colorado Climate Division 5: NOAA National Climatic Data Center, accessed May 20, 2019, at https://doi.org/10.7289/V5M32STR.

Yuan, Y., Khare, Y., Wang, X., Parajuli, P.B., Kisekka, I., and Finsterle, S., 2015, Hydrologic and water quality modelsSensitivity: Transactions of the ASABE, v. 58, no. 6, p. 1721-1744. [Also available at https://doi.org/10.13031/ trans.58.10611].

Zhou, T., Voisin, N., Leng, G., Huang, M., and Kraucunas, I., 2018, Sensitivity of regulated flow regimes to climate change in the Western United States: Journal of Hydrometeorology, v. 19, no. 3, p. 499-515. [Also available at https://doi.org/10.1175/JHM-D-17-0095.1]. 
For more information about this publication, contact

Director, New Mexico Water Science Center

U.S. Geological Survey

6700 Edith Blvd. NE

Albuquerque, NM 87113

For additional information visit

https://www.usgs.gov/centers/nm-water

Publishing support provided by

Lafayette Publishing Service Center 
